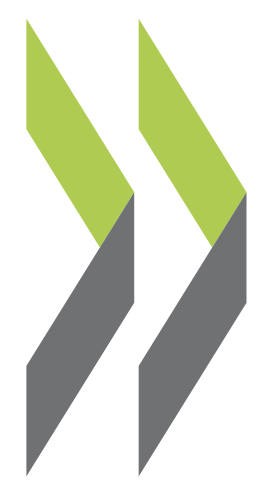

OECD Economics Department Working Papers No. 1497

Stabilising the Euro Area through unemployment benefits re-insurance
Guillaume Claveres,

scheme 
Organisation de Coopération et de Développement Économiques

Organisation for Economic Co-operation and Development

30-Jul-2018

ECONOMICS DEPARTMENT

English - Or. English

\section{STABILISING THE EURO AREA THROUGH AN UNEMPLOYMENT BENEFITS RE-INSURANCE SCHEME}

ECONOMICS DEPARTMENT WORKING PAPERS No. 1497

By Guillaume Claveres and Jan Stráský

OECD Working Papers should not be reported as representing the official views of the OECD or of its member countries. The opinions expressed and arguments employed are those of the author(s).

Authorised for publication by Isabell Koske, Deputy Director, Country Studies Branch, Economics Department.

All Economics Department Working Papers are available at www.oecd.org/eco/workingpapers

JT03434818

This document, as well as any data and map included herein, are without prejudice to the status of or sovereignty over any territory, to the delimitation of international frontiers and boundaries and to the name of any territory, city or area. 
OECD Working Papers should not be reported as representing the official views of the OECD or of its member countries. The opinions expressed and arguments employed are those of the author(s).

Working Papers describe preliminary results or research in progress by the author(s) and are published to stimulate discussion on a broad range of issues on which the OECD works.

Comments on Working Papers are welcomed, and may be sent to OECD Economics Department, 2 rue André Pascal, 75775 Paris Cedex 16, France, or by e-mail to eco.contact@oecd.org.

All Economics Department Working Papers are available at www.oecd.org/eco/workingpapers.

This document and any map included herein are without prejudice to the status of or sovereignty over any territory, to the delimitation of international frontiers and boundaries and to the name of any territory, city or area.

The statistical data for Israel are supplied by and under the responsibility of the relevant Israeli authorities. The use of such data by the OECD is without prejudice to the status of the Golan Heights, East Jerusalem and Israeli settlements in the West Bank under the terms of international law.

On 3 May 2018, the OECD Council invited Lithuania to become a Member. At the time of preparation the deposit of Lithuania's instrument of accession to the OECD Convention was pending and therefore Lithuania does not appear in the list of OECD Members and is not included in the OECD zone aggregates.

On 25 May 2018, the OECD Council invited Colombia to become a Member. At the time of preparation the deposit of Colombia's instrument of accession to the OECD Convention was pending and therefore Colombia does not appear in the list of OECD Members and is not included in the OECD zone aggregates.

\section{(c) OECD (2018)}

You can copy, download or print OECD content for your own use, and you can include excerpts from OECD publications, databases and multimedia products in your own documents, presentations, blogs, websites and teaching materials, provided that suitable acknowledgment of OECD as source and copyright owner is given. All requests for commercial use and translation rights should be submitted to rights@oecd.org 
ECO/WKP(2018)45

\section{ABSTRACT/RÉSUMÉ \\ Stabilising the Euro Area through unemployment benefits re-insurance scheme}

The paper examines the possible design and macroeconomic stabilisation properties of a euro area unemployment benefits re-insurance scheme using annual historical data from 2000 to 2016. The scheme we propose is similar in some aspects to the recent proposals, including the IMF's paper on the central fiscal capacity, while preserving important re-insurance characteristics, such as experience rating and caps on cumulative balances. Counterfactual simulations for individual euro area countries suggest that the scheme, at the cost of average annual contributions of $0.17 \%$ of national GDP, could have (i) provided additional macroeconomic stabilisation in the financial crisis of 2009-2013, both at the euro area level and at the level of individual countries hit by the crisis, and (ii) avoided permanent transfers among countries.

This Working Paper relates to the 2018 OECD Economic Survey of the Euro Area

(http://www.oecd.org/eco/surveys/economic-survey-european-union-and-euro-area.htm).

JEL classification: E61, E62, F42, F45, H87

Keywords: Macroeconomic stabilisation, fiscal integration, risk-sharing, transfer scheme

\section{$* * * * * * * * * *$ \\ Stabiliser la zone euro au moyen d'un régime de réassurance chômage}

Dans ce document, la possible conception d'un régime de réassurance chômage à l'échelle de la zone euro et ses éventuelles propriétés de stabilisation macroéconomique sont étudiés à partir de données historiques annuelles de la période 2000-16. Le modèle que nous présentons se rapproche sous certains aspects des propositions récentes, notamment celle avancée par le FMI dans son document sur la capacité budgétaire centrale, mais conserve des propriétés de réassurance importantes comme un système de bonusmalus et des plafonds de soldes cumulés. D'après les simulations contrefactuelles effectuées pour chaque pays de la zone euro, ce régime aurait pu, moyennant des contributions annuelles moyennes de $0.17 \%$ du PIB national, (i) constituer un vecteur de stabilisation macroéconomique supplémentaire lors de la crise financière de 2009-2013, au niveau de la zone euro comme au niveau des différents pays touchés par la crise, et (ii) éviter des transferts permanents entre les pays.

Ce Document de travail se rapporte à l'Étude économique de l'OCDE de la Zone Euro, 2018

(http://www.oecd.org/fr/eco/etudes/etude-economique-union-europeenne-et-zone-euro.htm)

Classification: E61, E62, F42, F45, H87

Mots clefs: stabilisation macroéconomique, intégration fiscale, partage des risques, procédure de transfert. 


\section{TABLE OF CONTENTS}

\section{STABILISING THE EURO AREA THROUGH AN UNEMPLOYMENT BENEFITS RE-INSURANCE SCHEME}

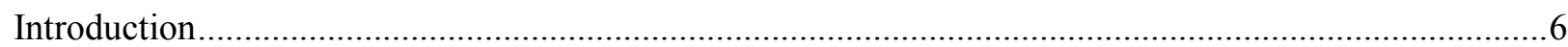

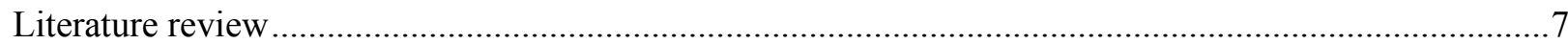

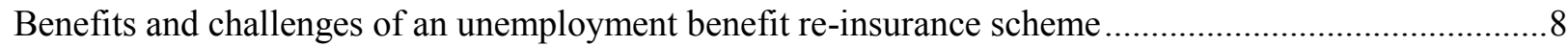

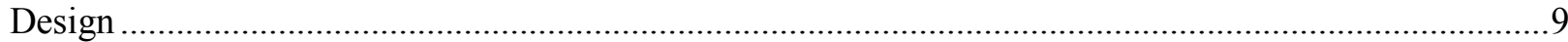

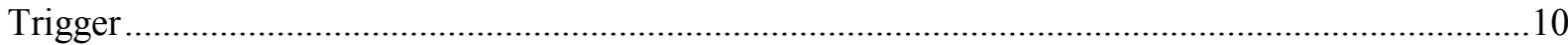

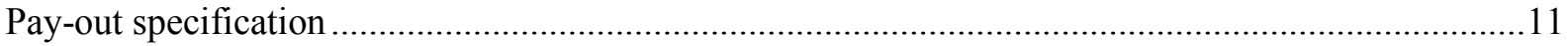

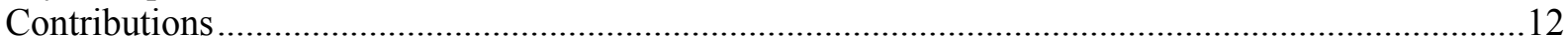

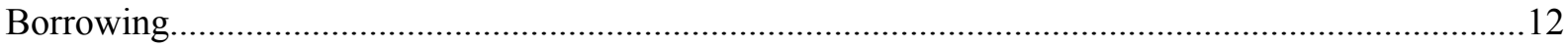

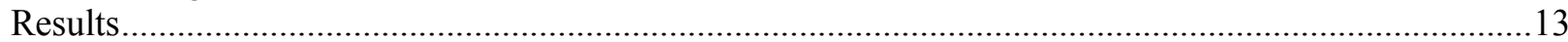

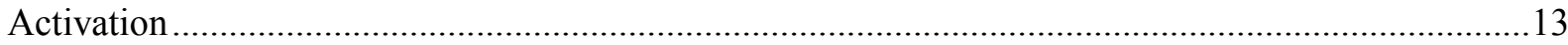

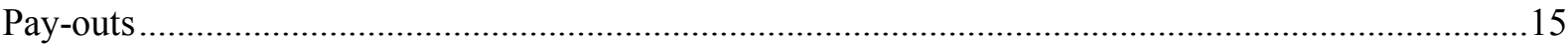

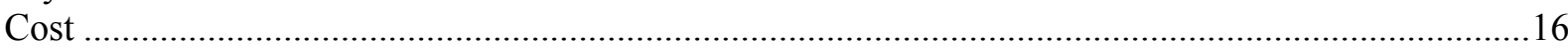

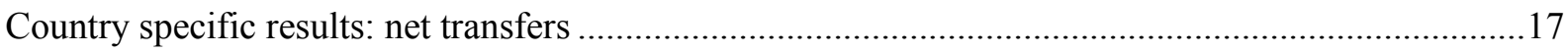

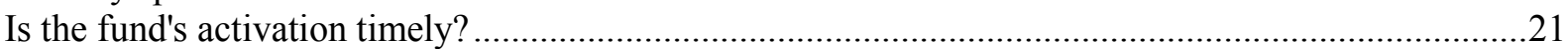

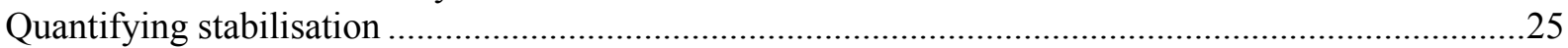

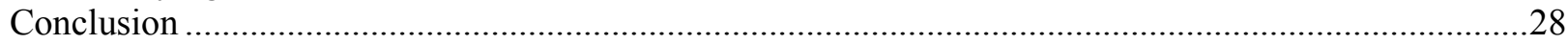

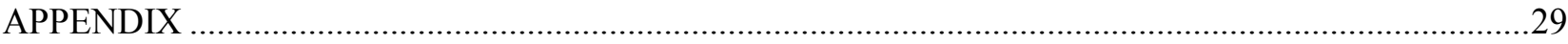

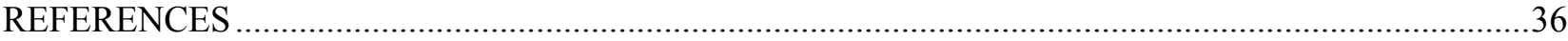

\section{Tables}

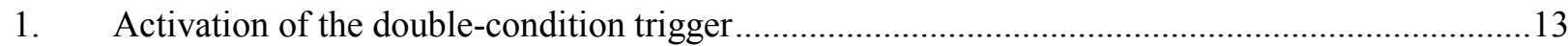

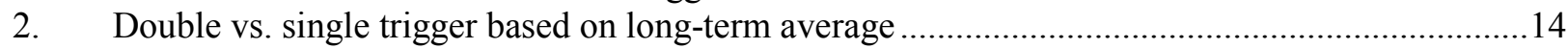

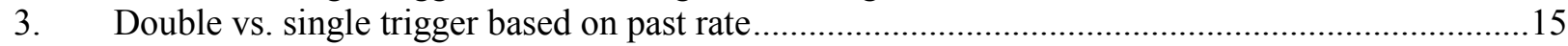

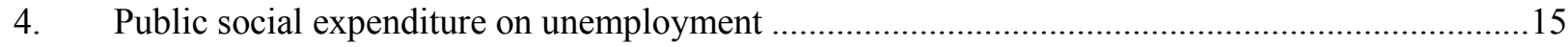

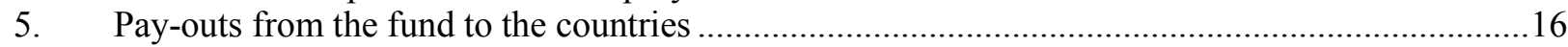

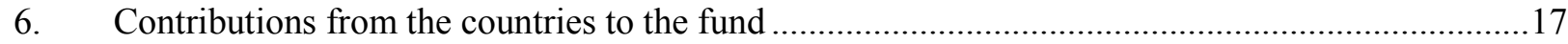

7. Net transfers to and from the unemployment benefit re-insurance scheme ...................................18

8. The scheme would reduce the standard deviation of real GDP growth .......................................26

9. Reduction of the standard deviation of real GDP growth with a multiplier of 1.5 ....................27

10. Reduction of the standard deviation of real GDP growth with a $2 \%$ GDP cap on scheme's

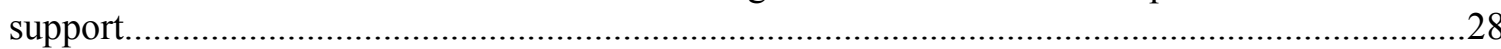

\section{Figures}

1. European unemployment fund would reinsure the existing national schemes...............................11

2. The fund would be indebted, but by very small amounts ..........................................................17

3. Pay-outs can be significant at times, but the average net transfers are close to zero ......................19

4. Cumulative net balances towards the fund remain contained .....................................................21

5. Support for member countries is triggered in a timely fashion...................................................22 


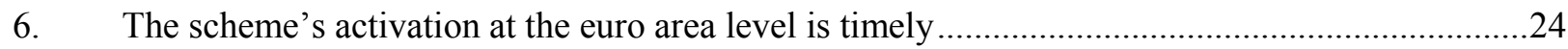

7. The EURS would deliver significant stabilisation for the euro area .........................................25

8. The scheme would improve stabilisation country by country....................................................26

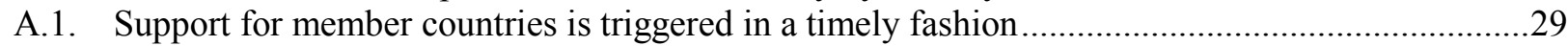

A.2. The EURS would improve stabilisation country by country ......................................................34 


\title{
STABILISING THE EURO AREA THROUGH AN UNEMPLOYMENT BENEFITS RE-INSURANCE SCHEME
}

\author{
Guillaume Claveres and Jan Stráský ${ }^{1}$
}

\section{Introduction}

1. A common fiscal stabilisation instrument for the euro area has been discussed since before the creation of the common currency. More recently, the financial and euro area sovereign debt crises have demonstrated that sound fiscal policies and their alignment are crucial in a monetary union where monetary policy only reacts to common shocks and member states retain important responsibilities for their fiscal and social policies. Temporary fiscal transfers would ease borrowing requirements and help making fiscal policies less pro-cyclical. Given the large spill-over effects from highly integrated trade flows and financial markets, such additional stabilisation capacity would benefit both the distressed countries and the whole euro area.

2. In case of a severe downturn, at the national or euro area level, national fiscal stabilisers may not be enough to absorb the shock and provide the needed amount of economic stabilisation. First, monetary policy may be constrained by the effective lower bound of policy rates, while non-performing loans and weakly capitalised banks may still impair monetary policy transmission, notably in the crisis countries. National fiscal policy will also be limited by trade leakages, high levels of debt in some countries and by generally low labour mobility. Finally, private risk sharing may not be sufficient in periods of market tensions and public institutions may need to reassure markets by providing a minimum level of shock absorption.

3. A cushioning of large macroeconomic shocks would make the euro area more resilient. However, to ensure political acceptance and long-run sustainability it is also important that the fiscal capacity contributes to ensuring joint fiscal discipline and prevents moral hazard, for example by being conditional on past compliance with the EU fiscal framework. These concerns have been acknowledged in the Five Presidents' Report's outline of the fiscal stabilisation function: it should not lead to permanent transfers between countries, preserve incentives for sound fiscal policy-making at the national level, be consistent with the EU fiscal framework and, finally, not replace the European Stability Mechanism as an instrument for crisis management (Juncker et al., 2015).

4. There are several ways, in which such fiscal capacity can be introduced. Indeed, the future euro area design is likely to be a mixture of several elements, including a loan or grant component alongside other expenditure-protecting measures. Accordingly, the European Commission proposed a multi-pronged fiscal stabilisation function for the euro area aimed at preserving investment levels in the event of large country-specific shocks (European Commission, 2017a).

5. In this paper, we provide counterfactual simulations of a euro area unemployment benefits reinsurance scheme that could serve as an important element of a future European fiscal stabilisation capacity. Crucially, the scheme presented here provides effective stabilisation against both country-specific and large area-wide shocks and finances its operations by emitting bonds on capital markets. The ability to borrow allows the fund to finance occasional deficits when pay-outs exceed contributions.

1. Jan Stráský is Economist at the European Union/Euro Area desk in the Country Studies Branch of the OECD Economics Department (Jan.STRASKY@oecd.org). At the time of writing, Guillaume Claveres was Junior Economist at the European Union/Euro Area desk in the Country Studies Branch of the OECD Economics Department. The authors would like to thank, without implicating, Pierre Beynet, Jarka Botev, Aida Caldera and Rory O'Farrell of the OECD, participants at the OECD Economics Department Brownbag seminar, as well as Nicolas Carnot, Gilles Mourre, Christophe Kamps and other European Commission and ECB officials for useful discussions and suggestions on earlier versions of the paper. The authors are also grateful to Patrizio Sicari for statistical assistance and Elisabetta Pilati for editorial assistance. All remaining errors are ours. 
6. The main findings of the paper are as follows. A euro area unemployment benefits re-insurance scheme according to our design could have reduced the standard deviation of euro area real GDP growth in the financial crisis, from 2009 to 2013 , by $0.24 \%$ from $2.33 \%$ to $2.09 \%$ (roughly a $10 \%$ reduction). In order to do so, while avoiding permanent transfers, the scheme would have required average annual contributions of participating countries of around $0.17 \%$ of their national GDP from 2000 to 2016. Our results are robust to various parameter modifications and comparable to other studies in the literature.

7. The rest of the paper has the following structure: section 2 provides a brief review of literature, while section 3 discusses main benefits and challenges of the unemployment benefits re-insurance scheme. Section 4 discusses the simulation setup in more detail and section 5 provides a summary of the results. Section 6 concludes.

\section{Literature review}

8. The creation of a common fiscal instrument has been discussed since the early days of the Economic and Monetary Union. In the 1970s and 1980s, well before the creation of the common currency, the MacDougall Report and the Delors Report proposed a federal budget for the monetary area. More recently, Allard et al. (2013) analysed several options for creating a euro area fiscal capacity, including a stabilisation fund, a central budget and unemployment insurance. Similarly, the Commission's reflection paper on the deepening of EMU and the following communications propose a fiscal stabilisation function in three alternative forms, which could be potentially combined over time: an investment protection scheme, an unemployment reinsurance scheme and a rainy day fund (European Commission, 2017a, 2017b).

9. Looking more specifically at the option of the unemployment insurance at the euro area level, Dullien (2014) and Lellouch and Sode (2014) propose an introduction of a basic unemployment insurance that would replace part of the existing national unemployment benefit systems for short-term unemployed financed by a European social contribution levied on wages. Each participating country could continue to top up these payments to provide the desired level of social protection. For some participating countries, the stabilisation effect in the Great Recession would have reached $25 \%$ of the downturn (Dullien, 2014). Furthermore, Beblavý and Maselli (2014) compare two options: a harmonised European unemployment benefit scheme applying automatically to every eligible unemployed person and a reinsurance system that would transfer funds to national unemployment insurance schemes when unemployment increases above its normal level. They find that reinsurance offers a stronger stabilisation effect than the former option, for the same amount of support to member countries.

10. Similarly to our approach, Beblavý, Gros and Maselli (2015) analyse an EU-wide reinsurance scheme with an activation threshold (a deductible) and experience rating that would be suitable for stabilising major labour market shocks. Using a simple retrospective simulation from 2000 to 2012, they show that such a supranational fiscal stabiliser could, for a small average contribution, provide significant stabilisation benefits to the crisis-hit countries. On the other hand, Germany does not qualify for any payout from the scheme and remains a net contributor.

11. In addition to studies applying the re-insurance approach, other authors favour schemes that are close to rainy-day funds and limit permanent transfers in the long run through symmetry between pay-outs and contributions. Carnot, Kizior and Mourre (2017) analyse a euro area stabilisation instrument with a double condition over observed unemployment for triggering payments and contributions. The working of the scheme in good and bad times is fully symmetric and includes a form of experience rating as a further safeguard against permanent transfers. For a limited annual contribution of $0.1 \%$ of GDP, the scheme would provide total net annual support of about $0.5 \%$ of euro area's GDP in past downturns, with the overall net position capped by $-2 \%$ of the euro area GDP. 
12. Arnold et al. (2018) proposes a macroeconomic stabilisation fund financed by regular annual contributions to build assets in good times and make transfers to support countries in bad times. Similar to our proposal, their central fiscal capacity would require past compliance with the EU fiscal rules, with the support triggered by a transparent automatic trigger based on the unemployment rate deviation. They find that annual contributions of $0.35 \%$ of country's GDP would be sufficient to finance a large part of the operation of automatic stabilisers in the past euro area recessions.

13. Although it is clear that a fiscal stabiliser at a euro area level could provide additional relief to crisis-hit countries, the precise simulation results in our study and other similar studies based on historical data need to be treated with caution. Second-round general equilibrium effects are missing from the analysis, as this is not a general equilibrium model that would incorporate dynamic effects. This is why we complement our paper by a study of macroeconomic stabilisation properties of a euro area wide unemployment insurance scheme in Claveres and Stráský (2018). Looking at the unemployment insurance scheme in a context of general equilibrium model with endogenous zero lower bound constraint on monetary policy, we conclude that, at the zero lower bound, such a scheme can reduce real GDP drop following a shock by about one third.

\section{Benefits and challenges of an unemployment benefit re-insurance scheme}

14. Unemployment benefits are an important automatic stabiliser that directly supports demand by maintaining a certain level of income for the unemployed. The multiplier effect of unemployment benefit expenditure is large as it primarily replaces income of low-income households with high marginal propensity to consume. At the European level, there exist already common EU provisions regarding portability, and hence pooling, of some social benefits. For example, persons looking for a job in a country different from the one from which they receive their unemployment benefits, may, under certain conditions, be able to export the unemployment benefits for a limited period of time. However, this possibility is not strongly supported, as the workers are expected first to use up all possibilities of finding a new job in the country of previous employment before extending their search to other states.

15. However, the labour market conditions and institutions across the euro area remain widely diverse. A common unemployment insurance scheme that directly replaces part of national unemployment benefits would have to rely on different contribution rates in each country and their periodic adjustment, in order to avoid long-term transfers between countries. The unemployment benefit reinsurance schemes that provide support to national unemployment benefit schemes, rather than to the unemployed individuals, similarly apply varying contribution rates, such as the experience rating. Moving to a system with a uniform contribution rate would require further convergence of unemployment rates, probably through closer co-ordination of employment policies and reinforced European governance on labour market issues.

16. Precise attribution of the support funds (so-called earmarking) is not necessary, but could in principle improve the macroeconomic stabilisation properties, as funds could be channeled to highmultiplier spending, such as unemployment benefits, active labour market policies and public infrastructure investment (Beblavý and Maselli, 2014). There is no earmarking in the baseline specification of our scheme. Similar to Carnot, Kizior and Mourre (2017), the national governments are free to choose on which policies within the general budget to allocate the support funds, providing flexibility in accordance with the subsidiarity principle. On the other hand, in a scheme without earmarking, it is less clear which value of the fiscal multiplier should be applied to net pay-outs in the assessment of macroeconomic stabilisation properties. One approach is to assume a multiplier applying to a balanced composition of fiscal changes (Carnot, Kizior and Mourre, 2017); another possibility is to assume a multiplier of unity for all pay-outs from the scheme (Dullien et al., 2018). In our baseline analysis of stabilisation gains, we assume a multiplier of unity; as a robustness check, we also provide results for a multiplier of 1.5 applied to net pay-outs from (and contributions to) the scheme. 
17. In order to ensure broad consensus for a common unemployment benefit scheme, the moral hazard issues, potentially arising in an ex-post risk-sharing mechanism, such as a euro area unemployment benefits re-insurance scheme, need to be convincingly addressed. For example, if governments know that part of unemployment benefits will be paid by euro area transfers, they may decide not to introduce structural reforms increasing labour market flexibility (Feld and Osterloh, 2013). Making the access to the fund conditional on past compliance with the EU fiscal rules and regular debt sustainability assessment by the European Stability Mechanism could further reduce moral hazard risk and encourage responsible fiscal policies.

18. The moral hazard issues extend to potential negative consequences of a prolonged use of the scheme for medium- and long-term growth. Existing empirical evidence suggests that decreasing unemployment benefits leads to higher employment and these results are symmetric for increasing unemployment benefits (Égert and Gal, 2017). Although it is not easy to assess the duration of support based on a simple counterfactual simulation, our proposal incorporates important safeguards to prevent countries' over-reliance on the common unemployment reinsurance, including the cap on individual country's balances with the scheme and the flexibility to employ resources where they are most needed.

19. A well-designed scheme must also avoid permanent transfers. Although transfers among countries are inevitable in the short run, long run fiscal neutrality is an important precondition for euro area countries in considering a common fiscal capacity. Our paper analyses two main instruments for preventing long-term transfers among countries, namely an experience rating and a cap on cumulative net transfers and contributions. Even though both tools seem to work well in our simulation, the cap on transfers and contributions may be more robust and easier to calibrate, while an experience rating as a slow-moving memory mechanism may ensure more gradual application of the balancing constraint.

\section{Design}

20. Our version of a euro area unemployment benefits re-insurance scheme (EURS) incorporates the following elements:

- activation according to a pre-defined, unemployment-based trigger;

- partial coverage of negative shocks affecting national unemployment agencies, with support proportioned to the size of the shock, and a cap on country-specific cumulative balance towards the fund;

- financing through contributions from member countries but only when the fund's balance drops below a given threshold, to which we add an experience rating to ensure that those drawing more often on the fund also contribute more;

- borrowing in financial markets.

21. These characteristics follow an insurance logic. The EURS would cover only parts of the shocks, those causing sudden and severe rises in the unemployment rate, through the reinsurance of national unemployment benefits at a time when pressure on public finances is at the highest. Stabilizing the rest of the shocks is left at the country level. The objective is to finance occasionally high pay-outs from the scheme through small contributions. The fund is financed by country contributions and experience rating payments, but it does not accumulate assets in good times: as long as the pay-offs are not activated by crisis-hit countries, the scheme is inactive and its assets do not increase. 
22. We do not tackle in this paper legal, implementation or institutional issues linked to the feasibility of such scheme. For a study of these issues, we refer readers to Beblavý and Lenaerts (2017). Also, we do not specifically discuss the issue of access to the fund conditional on adherence to EU fiscal rules, addressed in the OECD 2018 Economic Survey of the Euro area.

\section{Trigger}

23. To ensure effectiveness, the capacity should be activated based on a transparent, certain and unbiased real-time measure of economic activity with limited ex-post revisions. Transfer rules based on output gap seem particularly ineffective, due to the problems related to their real-time estimation. Unemployment rate appears a better indicator to operate transfers in real time, given its close correspondence to the cyclical position, harmonised measurement across the euro area countries and stability to revisions (Arnold et al., 2018). One limitation of using the unemployment rate as an indicator for the trigger and the calculation of pay-outs is that the rate for a given year is only available with a delay. In real time, the scheme would either have to be based on estimated unemployment data for the current year or transfers for a given year could be distributed in the following year, once data becomes available. However the latter option could have implications in terms of stabilization and timeliness of transfers. Additional counterfactual simulations could be carried out to analyse this issue.

24. In order to limit discretionary policy and ensure timeliness of the transfers, the trigger mechanism should be agreed ex ante and operate in an automatic manner, based on a double condition. The double condition trigger would activate the scheme when the unemployment rate is both increasing and above the long-term average (calculated as a 10-year moving average), which is likely to happen at the beginning of the downturn. However, the support would not be maintained when the unemployment rate stops increasing, or if the unemployment rate settles at a higher level for a prolonged period of time. The double condition trigger would also limit moral hazard: since countries with stable unemployment would stop receiving pay-outs, incentives for countries to reform their labour markets and lower structural unemployment would be preserved.

25. In contrast, a single condition trigger could increase the risk of untimely payments. If based solely on year-on-year changes in the current unemployment rate, there could be a pay-out when unemployment is rising while below its long-term average, in which case the country may not be in a downturn or only facing a small fluctuation. If based on the long-term average only, support could be maintained because the unemployment rate is still above the long-term average while decreasing, which could be the case if the country is recovering fast from a past downturn. In both these cases, it can be argued that supporting the country is not warranted. On the other hand, a more gradual phasing out of the support could be justified when unemployment is still at a very high level and not decreasing fast, as observed in some of the former euro area crisis countries, such as Greece.

26. Finally, our re-insurance scheme has attractive features compared to a genuine unemployment insurance scheme. In a genuine variant of the euro area unemployment insurance scheme, the central fund pays unemployment benefits directly and continuously to all eligible euro area unemployed workers. Since such a scheme would be active in all periods, not restricted to large shocks, potential moral hazard would be higher. Such a scheme would also likely require further harmonisation of heterogeneous national unemployment insurance systems in terms of duration, eligibility and replacement ratios (Dolls et al., 2014). In the absence of further harmonisation, a genuine system would have to be aligned to the lowest common denominator in terms of unemployment insurance, limiting its stabilisation capacity. On the contrary, an unemployment re-insurance scheme can succeed even with limited convergence, as it only reinsures national agencies according to a pre-defined transfer amount (Figure 1). 
Figure 1. European unemployment fund would reinsure the existing national schemes

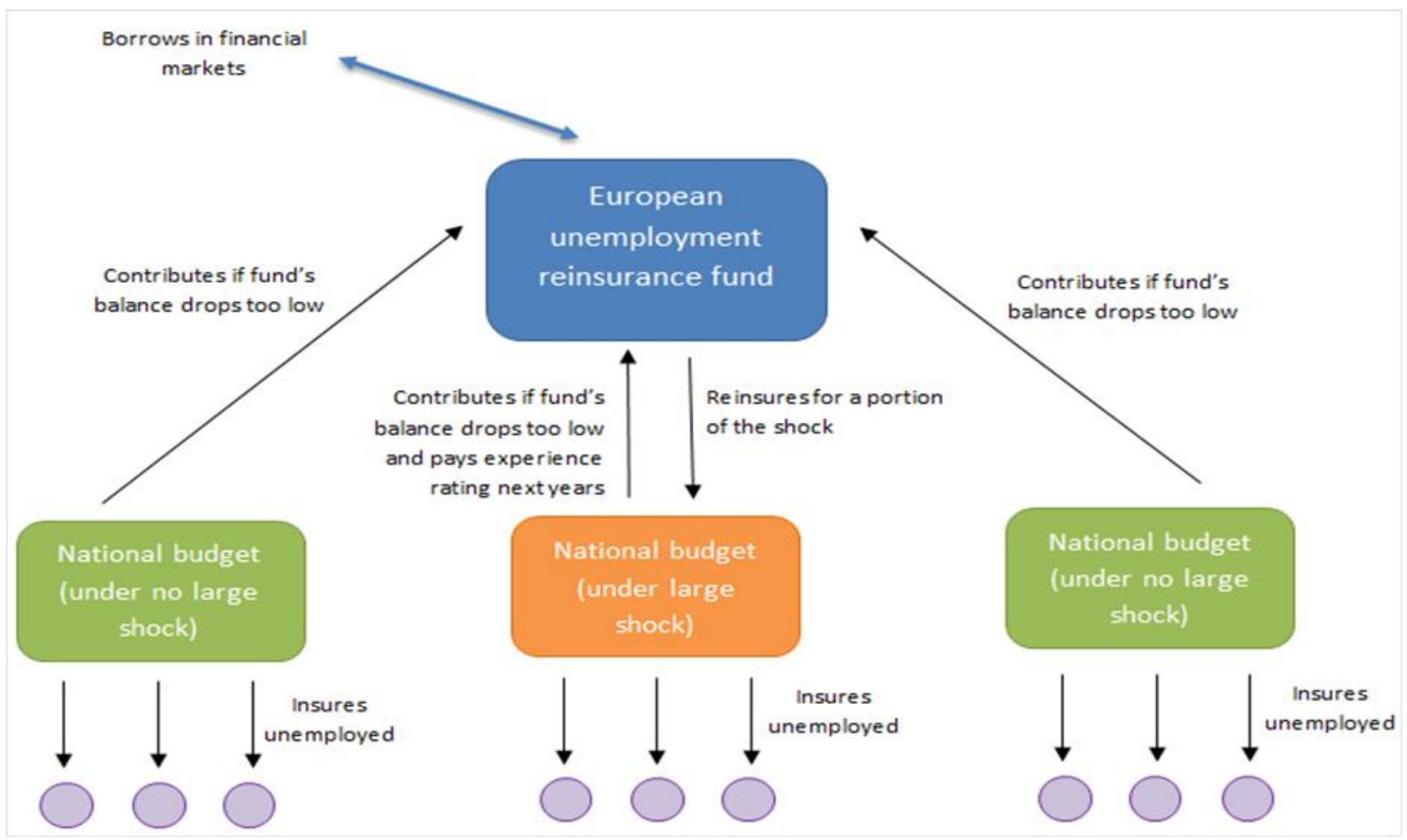

\section{Pay-out specification}

27. The size of the pay-out is a function of the increase in the unemployment rate, so that the amount of the support is linked to the severity of the shock. When activated, the scheme pays out to the national agency an amount equivalent to $1 \%$ of GDP times the change in the unemployment rate. This means that a country experiencing a 1 percentage point increase in the unemployment rate (with current rate above the 10 -year average) would receive transfer amounting to $1 \%$ of its GDP.

28. Such pay-outs can, in exceptional circumstances, lead to high transfers. This could prove problematic for two reasons. First, some countries might run high and growing positive positions towards the fund (i.e. they receive big pay-outs for several years), which could prove politically difficult. It is possible that even with contributions including the experience rating they remain net recipients in cumulated terms for a long period of time. Second, there could be some years when unemployment agencies could have difficulties absorbing the received transfers. For these reasons we limit pay-outs by capping country-specific cumulative balances with the fund. Support could not increase the cumulated position of a country towards the fund above $5 \%$ of its GDP. This helps preventing balances to build up to excessively high levels. It also to some extent limits one-time high pay-outs, although they still occur in some cases.

29. Our choice for the scale of the scheme is to some extent arbitrary, mostly comparable to existing studies, and set comparable to shifts in GDP and cyclical deficits for member countries and the euro area as a whole. These parameters should not be seen as strong recommendations, but rather as indication of how the fund would perform if it faced severe crises such as the financial and sovereign debt crisis. If needed, the scheme could be scaled down or up, leading to proportionate results while preserving its overall functioning. 


\section{Contributions}

30. Contributions from member countries to the fund are made of two components. The first consists in start-stop payments of $0.1 \%$ of GDP per year from all countries, payable when the fund's balance dropped below $-0.5 \%$ of euro area GDP at the end of the previous year. By definition, in "a steady-statelike" situation where countries do not activate the fund and its balance is above this threshold the scheme is completely inactive (leaving aside the experience rating payments, described below). There is no extra effort in times of growth, as the logic is not one of stabilizing booming economies or building fiscal buffers in good times, leaving these objectives solely at the national level, in accordance with the European fiscal framework. However, if it is considered important that the fund accumulates assets in good times, the threshold could be set in positive territory so that the countries keep paying start-stop contributions until the fund's balance is positive.

31. The start-stop payment approach has an advantage over contributions based on a symmetric trigger for pay-outs and pay-ins. According to a symmetric trigger, contributions could occur when the unemployment is decreasing and below a long-term average (just as pay-outs are triggered when unemployment rate is rising and above the long-term average), instead of only kicking-in when the fund's balance drops. However, with a symmetric trigger, countries could also incur an extra cost for implementing structural reforms to lower their unemployment rate. If successful, such a reform would lower temporarily the unemployment rate below the long-term average, triggering contributions at the same time when the reform has to be financed. This does not happen in our set-up: contributions do not occur, beyond the start-stop payments, when a country has its unemployment rate decreasing.

32. The second component of country contributions consists in experience rating. For each time the trigger was activated over the past 10 years, an additional contribution is paid amounting to $0.05 \%$ of GDP. Hence, at maximum if the fund activated 10 times the premium amounts to $0.5 \%$ of GDP for a total of $0.6 \%$ if there is an annual contribution that same year. According to this slow-moving memory mechanism, higher contributions would be charged to countries consistently drawing on the fund, which helps in preventing permanent transfers.

33. Compared to claw-backs, contributions would gradually rise but a country would not have to pay back the received amounts according to a pre-defined schedule. Indeed, this could prove ineffective as a country could have to repay while still recovering, potentially prolonging the negative shock. Instead, with experience rating, a country still in crisis or facing a double-dip recession would still be supported in net terms as long as it activates the trigger but then, as it recovers and the triggers stops, experience rating would result in net contributions to the fund. However, the system does not completely rule out cases where a country would have to contribute in net terms to the fund while in bad economic situation. As discussed in the results section, our counterfactual simulations show that negative net transfers would be charged in a year of recession in $7.6 \%$ of cases.

34. In order to prevent contributions kicking-in when the country is still not in a very good economic state, one could also consider applying the experience rating only after a time lag or only when it is considered that the country has recovered. However, this would introduce additional discretion on how countries would be charged with experience rating, since the proper delay for payment or circumstances under which the country is deemed in recovery could be subjected to interpretation and negotiations.

\section{Borrowing}

35. The scheme should be allowed to borrow in financial markets, so as to cover occasional deficits when built-up contributions are not enough to cover the pay-outs. Otherwise, the stabilisation potential of the scheme would be greatly reduced. The borrowing of the fiscal capacity in the financial markets could 
be similar to that of the European Investment Bank and the European Stability Mechanism, where countries have provided a significant but limited amount of capital and guarantees to the two institutions that can leverage themselves on the market and provide loans to the private and public sector, respectively (Claeys, 2017). The EURS borrowing could similarly make use of guarantees in the form of callable capital, while limiting the liability of each participating country to its portion of the guarantee.

36. Counterfactual simulations show that the debt issued would anyway represent a small percentage in terms of euro area GDP, about $2 \%$ at most. Hence, also considering the design features of the scheme (in particular the start-stop contributions ensuring payments as long as the fund's balance drops low), it is likely that the debt would be granted a high rating.

\section{Results}

37. We run counterfactual simulations from 2000 to 2016 based on available euro area data. We want to assess the performance of the EURS in terms of timeliness and the macroeconomic stabilization effects it could deliver. Regarding country coverage, euro area members that are also members of the OECD (16 countries) are included in the computations, from the year they joined the euro provided data is available. We use annual data on real GDP from 2000 to 2016 and annual data on unemployment rates from 1990 to 2016, obtained from the OECD Economic Outlook database. The unemployment data is used to compute the long-term average of the unemployment rate, defined as the 10 -year moving average.

\section{Activation}

38. The double condition described above would have activated the fund 81 times out of 222 cases from 2000 to 2016, which is the equivalent of $36 \%$ of the total of country-years (Table 1). The scheme would have been activated in most countries in 2008-2009, and again in 2012-2013. Over the whole simulation period, the fund would have activated at most 10 times for Austria, Luxembourg and Portugal.

\begin{tabular}{|c|c|c|c|c|c|c|c|c|c|c|c|c|c|c|c|c|}
\hline & AUT & BEL & DEU & ESP & EST & FIN & FRA & GRC & IRL & ITA & LUX & LVA & NLD & PRT & SVK & SVN \\
\hline \multicolumn{17}{|l|}{2000} \\
\hline \multicolumn{17}{|l|}{2001} \\
\hline 2002 & $T$ & & $\mathrm{~T}$ & & & & & & & & $\mathrm{~T}$ & & & & & \\
\hline 2003 & $\mathrm{~T}$ & & $\mathrm{~T}$ & & & & & & & & $\mathrm{~T}$ & & & $\mathrm{~T}$ & & \\
\hline 2004 & $\mathrm{~T}$ & & $\mathrm{~T}$ & & & & & & & & $\mathrm{~T}$ & & $\mathrm{~T}$ & $\mathrm{~T}$ & & \\
\hline 2005 & $T$ & $T$ & $T$ & & & & & & & & $\mathrm{~T}$ & & $T$ & $\mathrm{~T}$ & & \\
\hline 2006 & & & & & & & & & & & $\bar{T}$ & & & $\bar{T}$ & & \\
\hline 2007 & & & & & & & & & & & & & & $\mathrm{~T}$ & & \\
\hline 2008 & . & & & $T$ & & & & & $\mathrm{~T}$ & & . & & & & & \\
\hline 2009 & $\bar{T}$ & $T$ & & $T$ & & & $\mathrm{~T}$ & & $T$ & & $\mathrm{~T}$ & & $\mathrm{~T}$ & $\mathrm{~T}$ & & \\
\hline 2010 & & $\mathrm{~T}$ & & $\mathrm{~T}$ & & $\mathrm{~T}$ & $\mathrm{~T}$ & $\mathrm{~T}$ & $\mathrm{~T}$ & $\mathrm{~T}$ & $\mathrm{~T}$ & & $\mathrm{~T}$ & $\mathrm{~T}$ & & $\mathrm{~T}$ \\
\hline 2011 & & & & $\mathrm{~T}$ & & & & $\mathrm{~T}$ & $\mathrm{~T}$ & $\mathrm{~T}$ & & & & $\mathrm{~T}$ & & $\mathrm{~T}$ \\
\hline 2012 & $T$ & & & $T$ & & & $\mathrm{~T}$ & $T$ & $\mathrm{~T}$ & $\mathrm{~T}$ & $\mathrm{~T}$ & & $\mathrm{~T}$ & $\mathrm{~T}$ & & $T$ \\
\hline 2013 & $\mathrm{~T}$ & $\mathrm{~T}$ & & $\mathrm{~T}$ & & $\mathrm{~T}$ & $\mathrm{~T}$ & $\mathrm{~T}$ & & $\mathrm{~T}$ & $\mathrm{~T}$ & & $\mathrm{~T}$ & $\mathrm{~T}$ & $\mathrm{~T}$ & $\mathrm{~T}$ \\
\hline 2014 & $\mathrm{~T}$ & $\mathrm{~T}$ & & & & $\mathrm{~T}$ & $\mathrm{~T}$ & & & $\mathrm{~T}$ & $\mathrm{~T}$ & & $\mathrm{~T}$ & & & \\
\hline 2015 & $T$ & & & & & $\mathrm{~T}$ & $\mathrm{~T}$ & & & & & & & & & \\
\hline 2016 & $T$ & & & & & & & & & & & & & & & \\
\hline
\end{tabular}

Note: darker cells indicate that countries are not included in the scheme, either because of data availability or the later start of the euro area membership. 


\section{ECO/WKP(2018)45}

39. Had the trigger been based on a single condition only, consisting of the current unemployment rate being above its 10-year average, the fund would have activated instead in $53 \%$ of cases, but this includes years where the unemployment is decreasing (Table 2). For example, with a single condition on the long-term average, support would be provided for Spain from to 2014 to 2016 because its unemployment rate was above the long term average, but it was decreasing from 2014 onwards. Table 2 shows in which cases the support would be ruled out by the double condition trigger ( $17 \%$ of cases).

40. The double condition trigger also filters out increases in the unemployment rate, in the situation when unemployment is lower than the long-term average. Had the trigger been based on a single condition where the unemployment rate has to be increasing, but can be lower than the long-term average, the scheme would activate in $48 \%$ of cases. But there would be support in times of low unemployment relative to the long-term average. For example, France would trigger support from 2002 to 2005, although its unemployment rate only increased by $0.2 \%$ per year on average for that period. Table 3 shows years where the double trigger rules out activations for years when the unemployment rate stays below its long-term average ( $13 \%$ of cases).

Table 2. Double vs. single trigger based on long-term average

\begin{tabular}{|c|c|c|c|c|c|c|c|c|c|c|c|c|c|c|c|c|}
\hline & AUT & BEL & DEU & ESP & EST & FIN & FRA & GRC & IRL & ITA & LUX & LVA & NLD & PRT & SVK & SVN \\
\hline 2000 & & & & & & & & & & & $S$ & & & & & \\
\hline 2001 & & & & & & & & & & & & & & & & \\
\hline 2002 & $D$ & & $D$ & & & & & & & & $D$ & & & & & \\
\hline 2003 & $D$ & & $\mathrm{D}$ & & & & & & & & $D$ & & & $D$ & & \\
\hline 2004 & $\mathrm{D}$ & & D & & & & & & & & D & & D & D & & \\
\hline 2005 & $\mathrm{D}$ & $D$ & $D$ & & & & & & & & $D$ & & D & $D$ & & \\
\hline 2006 & $S$ & $S$ & $S$ & & & & & & & & $D$ & & $S$ & $D$ & & \\
\hline 2007 & $\mathrm{~S}$ & & & & & & & & & & S & & & D & & \\
\hline 2008 & & & & $\mathrm{D}$ & & & & & $\mathrm{D}$ & & S & & & $S$ & & \\
\hline 2009 & D & D & & D & & & D & & D & & D & & D & D & & \\
\hline 2010 & $S$ & $\mathrm{D}$ & & $\mathrm{D}$ & & $\mathrm{D}$ & $\mathrm{D}$ & $\mathrm{D}$ & $\mathrm{D}$ & $\mathrm{D}$ & $\mathrm{D}$ & & D & $\mathrm{D}$ & & $\mathrm{D}$ \\
\hline 2011 & & & & D & $S$ & & S & D & $\mathrm{D}$ & D & $S$ & & S & D & & D \\
\hline 2012 & $\mathrm{D}$ & & & $\mathrm{D}$ & $\mathrm{S}$ & & $\mathrm{D}$ & D & $\mathrm{D}$ & $\mathrm{D}$ & $\mathrm{D}$ & & $\mathrm{D}$ & $\mathrm{D}$ & & $\mathrm{D}$ \\
\hline 2013 & $D$ & $\mathrm{D}$ & & $\mathrm{D}$ & & $D$ & $\mathrm{D}$ & D & $S$ & $\mathrm{D}$ & $D$ & & $D$ & $D$ & $\mathrm{D}$ & $\mathrm{D}$ \\
\hline 2014 & $\mathrm{D}$ & D & & $\mathrm{S}$ & & $\mathrm{D}$ & D & S & $\mathrm{S}$ & D & D & & D & S & & S \\
\hline 2015 & $\mathrm{D}$ & $S$ & & $S$ & & $\mathrm{D}$ & $\mathrm{D}$ & $S$ & & $S$ & $S$ & & $S$ & $S$ & & $S$ \\
\hline 2016 & D & & & $S$ & & $S$ & $S$ & $S$ & & $S$ & S & & S & & & $S$ \\
\hline
\end{tabular}

Note: Cells labelled " $D$ " refer to years when the double condition trigger activates as in the baseline set-up (36\% of cases). Cells labelled "S" refer to years when the double condition trigger would not activate, but a single condition trigger based on the unemployment rate increasing above the $10 y$ moving average would ( $17 \%$ of cases). Darker cells indicate that countries are not included in the scheme, either because of data availability or the later start of the euro area membership. 
ECO/WKP(2018)45

Table 3. Double vs. single trigger based on past rate

\begin{tabular}{|c|c|c|c|c|c|c|c|c|c|c|c|c|c|c|c|c|}
\hline & AUT & BEL & DEU & ESP & EST & FIN & FRA & GRC & IRL & ITA & LUX & LVA & NLD & PRT & SVK & SVN \\
\hline 2000 & & & & & & & & & & & & & & & & \\
\hline 2001 & $S$ & & & & & & & & & & & & & & & \\
\hline 2002 & $D$ & $\mathrm{~S}$ & $D$ & $\mathrm{~S}$ & & & $\mathrm{~S}$ & & $S$ & & $\mathrm{D}$ & & $S$ & $S$ & & \\
\hline 2003 & $D$ & $S$ & $\mathrm{D}$ & $\mathrm{S}$ & & & $\mathrm{S}$ & & $\mathrm{S}$ & & $D$ & & $\mathrm{~S}$ & $D$ & & \\
\hline 2004 & $D$ & $S$ & $D$ & & & & $\mathrm{~S}$ & & & & $D$ & & $D$ & $D$ & & \\
\hline 2005 & D & D & D & & & & $\mathrm{S}$ & & & & D & & D & D & & \\
\hline 2007 & & & & & & & & & $S$ & & & & & $D$ & & \\
\hline 2008 & & & & $D$ & & & & & $\mathrm{D}$ & $\mathrm{S}$ & & & & & & \\
\hline 2009 & D & D & $\mathrm{S}$ & D & & $S$ & D & $\mathrm{S}$ & D & $S$ & D & & D & D & $\mathrm{S}$ & S \\
\hline 2010 & & D & & D & & D & D & D & D & D & D & & D & D & $S$ & D \\
\hline 2011 & & & & $D$ & & & & $D$ & D & $D$ & & & & $D$ & & D \\
\hline 2016 & $D$ & & & & $S$ & & & & & & & & & & & \\
\hline
\end{tabular}

Note: Cells labelled " $D$ " refer to years when the double condition trigger activates as in the baseline set-up (36\% of cases). Cells labelled "S" refer to years when the double condition trigger would not activate, but a single condition trigger based on the unemployment rate increasing compared to past rate would (13\% of cases). Darker cells indicate that countries are not included in the scheme, either because of data availability or the later start of the euro area membership.

\section{Pay-outs}

41. Averaged over the whole period, the fund transfers an average pay-out of $0.25 \%$ of GDP per year. However, a more telling figure for a scheme based on an insurance logic is the non-zero average payout since a simple average of the pay-outs includes all the cases where there is not pay-out at all. When it does activate (in $36 \%$ of cases), the fund provides on average a pay-out of $0.75 \%$ of GDP. In 2009, total pay-outs provided by the fund to all countries in our simulation amount to $0.88 \%$ of euro area GDP. As a comparison figure, on average from 2000 to 2013, the euro area (including the countries in the simulation) spent $1.3 \%$ of GDP in social public expenditure related to unemployment (Table 4).

Table 4. Public social expenditure on unemployment

As per cent of GDP

\begin{tabular}{|c|c|c|c|c|c|c|c|c|c|c|c|c|c|c|c|c|c|}
\hline & AUT & BEL & DEU & ESP & EST & FIN & FRA & GRC & IRL & ITA & LUX & LVA & NLD & PRT & SVK & SVN & $\begin{array}{c}\text { EA } \\
\text { average }\end{array}$ \\
\hline 2000 & 0.92 & 2.74 & 1.31 & 1.64 & 0.13 & 2.12 & 1.41 & 0.39 & 0.83 & 0.39 & 0.34 & 0.55 & 1.18 & 0.63 & 0.64 & 0.86 & 1.00 \\
\hline 2005 & 1.11 & 3.21 & 1.83 & 1.81 & 0.11 & 1.93 & 1.66 & 0.40 & 0.91 & 0.47 & 0.99 & 0.37 & 1.48 & 1.33 & 0.26 & 0.59 & 1.15 \\
\hline 2010 & 1.00 & 3.51 & 1.47 & 3.19 & 0.59 & 1.94 & 1.60 & 0.84 & 3.24 & 1.45 & 1.18 & 1.07 & 1.45 & 1.24 & 0.67 & 0.54 & 1.56 \\
\hline 2013 & 0.99 & 3.23 & 1.03 & 3.11 & 0.33 & 1.94 & 1.63 & .. & 2.54 & 1.70 & 1.43 & 0.49 & 1.62 & 1.61 & 0.43 & 0.75 & 1.52 \\
\hline $\begin{array}{c}\text { Average } \\
2000- \\
2013\end{array}$ & 1.01 & 3.17 & 1.41 & 2.43 & 0.29 & 1.98 & 1.57 & 0.54 & 1.88 & 1.00 & 0.98 & 0.62 & 1.43 & 1.20 & 0.50 & 0.68 & 1.31 \\
\hline
\end{tabular}

42. A comparison of average and non-zero average pay-outs can also be made at the country level. For example, the average pay-out that Ireland receives from 2000 to 2016 amounts to $0.36 \%$ of its GDP per year, but taking only the years for which it did receive a payment, from 2008 to 2012, the average payout is $1.24 \%$. This again is due to the insurance principle: the fund does not activate often but when it does 


\section{ECO/WKP(2018)45}

it can provide significant payments for some countries. On the contrary, for Austria, the fund would have provided support for a total of 10 years, but for smaller amounts, so that the average and non-average payouts for Austria are not too different, $0.28 \%$ and $0.47 \%$ respectively. Table 5 displays average and nonzero average payments country by country as well as for the EA level.

Table 5. Pay-outs from the fund to the countries

As per cent of GDP

\begin{tabular}{|c|c|c|c|c|c|c|c|c|c|c|c|c|c|c|c|c|c|}
\hline & AUT & BEL & DEU & ESP & EST & FIN & FRA & GRC & IRL & ITA & LUX & LVA & NLD & PRT & SVK & SVN & $\begin{array}{c}\text { EA } \\
\text { average }\end{array}$ \\
\hline $\begin{array}{l}\text { Average } \\
\text { Pay-out }\end{array}$ & 0.28 & 0.14 & 0.21 & 0.37 & 0.00 & 0.10 & 0.18 & 0.45 & 0.36 & 0.29 & 0.30 & 0.00 & 0.28 & 0.48 & 0.03 & 0.53 & 0.25 \\
\hline $\begin{array}{c}\text { Non-zero } \\
\text { average } \\
\text { Pay-out }\end{array}$ & 0.47 & 0.49 & 0.80 & 1.04 & 0.00 & 0.45 & 0.52 & 2.71 & 1.24 & 0.98 & 0.51 & 0.00 & 0.69 & 0.82 & 0.27 & 1.06 & 0.75 \\
\hline$\underset{\text { pay-out }}{\text { Maximum }}$ & 1.21 & 0.94 & 1.09 & 3.02 & 0.00 & 0.70 & 1.74 & 3.10 & 3.75 & 2.27 & 1.31 & 0.00 & 1.43 & 1.88 & 0.27 & 1.37 & 1.50 \\
\hline $\begin{array}{l}\text { Number of } \\
\text { activation } \\
\text { out of total } \\
\text { of years }\end{array}$ & $10 / 17$ & $5 / 17$ & $4 / 15$ & $6 / 17$ & $0 / 6$ & $4 / 17$ & $6 / 17$ & $4 / 12$ & $5 / 17$ & $5 / 17$ & $10 / 17$ & $0 / 3$ & $7 / 17$ & $10 / 17$ & $1 / 8$ & $4 / 8$ & $81 / 222$ \\
\hline
\end{tabular}

43. Although annual pay-outs as a fraction of GDP are in general moderate, there are several exceptional cases, most notably Spain in 2008 (3.02\%), Greece in 2010 (3.1\%) and Ireland in 2009 (3.75\%). The cap on cumulative balances prevents these exceptional amounts from rising further: for example, without a cap, Spain would have received a 6.60\% pay-out in 2009 instead. As shown below, the cap also prevents growing imbalances towards the fund.

44. However, even with the cap, annual net transfers can be substantial. As noted above, the situation where national agencies receive amounts equivalent to several percentage points of GDP in one year, and possibly no pay-out at all the following year, could lead to operational and implementation difficulties. National budgets would then have to face stopping support after a year when they absorb an important inflow from the fund. To deal with these situations, the design could be augmented so that support is tapered out over the years: only a part of the transfer would be distributed in the year of the activation, and remaining portion stored in a country-specific compartment to be distributed gradually during subsequent years. The total amount of transfer would be spread out over a longer period, avoiding both one-time big pay-outs and abrupt cuts in support. Because such feature would have implications in terms of permanent transfers and timeliness of assistance, it would require additional discussion.

\section{Cost}

45. Countries contribute to the fund through annual contributions made of a start-stop portion (when the fund's balance drops below $-0.5 \%$ of euro area GDP) and an experience rating portion (when the country has drawn on the fund in past years). On average, the fund charges an annual contribution of $0.17 \%$ of GDP (and a $0.21 \%$ non-zero average contribution). From 2000 to 2002, it does not charge a contribution at all and is completely inactive. The highest country contribution amounts to $0.55 \%$ in 2013 for Portugal, since at that time start-stop contributions kick-in and Portugal has been drawing 9 times on the fund for the past 10 year. Table 6 shows average, non-zero average and maximum contributions by country. 
ECO/WKP(2018)45

Table 6. Contributions from the countries to the fund

In per cent of GDP

\begin{tabular}{|c|c|c|c|c|c|c|c|c|c|c|c|c|c|c|c|c|c|}
\hline & AUT & BEL & DEU & ESP & EST & FIN & FRA & GRC & IRL & ITA & LUX & LVA & NLD & PRT & SVK & SVN & $\begin{array}{c}\text { EA } \\
\text { average }\end{array}$ \\
\hline $\begin{array}{c}\text { Average } \\
\text { Contribution }\end{array}$ & 0.24 & 0.15 & 0.21 & 0.17 & 0.10 & 0.11 & 0.14 & 0.17 & 0.16 & 0.13 & 0.28 & 0.10 & 0.19 & 0.29 & 0.12 & 0.21 & 0.17 \\
\hline $\begin{array}{c}\text { Non-zero } \\
\text { average } \\
\text { contribution }\end{array}$ & 0.29 & 0.20 & 0.23 & 0.24 & 0.10 & 0.15 & 0.20 & 0.18 & 0.23 & 0.18 & 0.34 & 0.10 & 0.25 & 0.38 & 0.12 & 0.21 & 0.21 \\
\hline $\begin{array}{l}\text { Maximum } \\
\text { contribution }\end{array}$ & 0.35 & 0.35 & 0.30 & 0.40 & 0.10 & 0.30 & 0.40 & 0.30 & 0.35 & 0.35 & 0.45 & 0.10 & 0.40 & 0.55 & 0.15 & 0.30 & 0.32 \\
\hline
\end{tabular}

46. With lower contributions than pay-outs on average, the fund is over the period unbalanced and would have to run debt, although relatively small in terms of per cent of EA GDP (Figure 2). The fund's balance would not drop below $-1 \%$ of EA GDP until the financial crisis in 2008, and then would decrease to $-2 \%$ in 2013 before running surpluses towards the end of the simulation period to settle at $-1.16 \%$ in 2016. This is consistent with the fund having to face these two crises, and similarly the fund proposed by Carnot, Kizior and Mourre (2017) also operates between 0 and -2\% of GDP for their long run simulation from 1985 to 2016 .

Figure 2. The fund would be indebted, but by very small amounts ${ }^{1}$

Overall balance of the common fund, as per cent of the euro area GDP

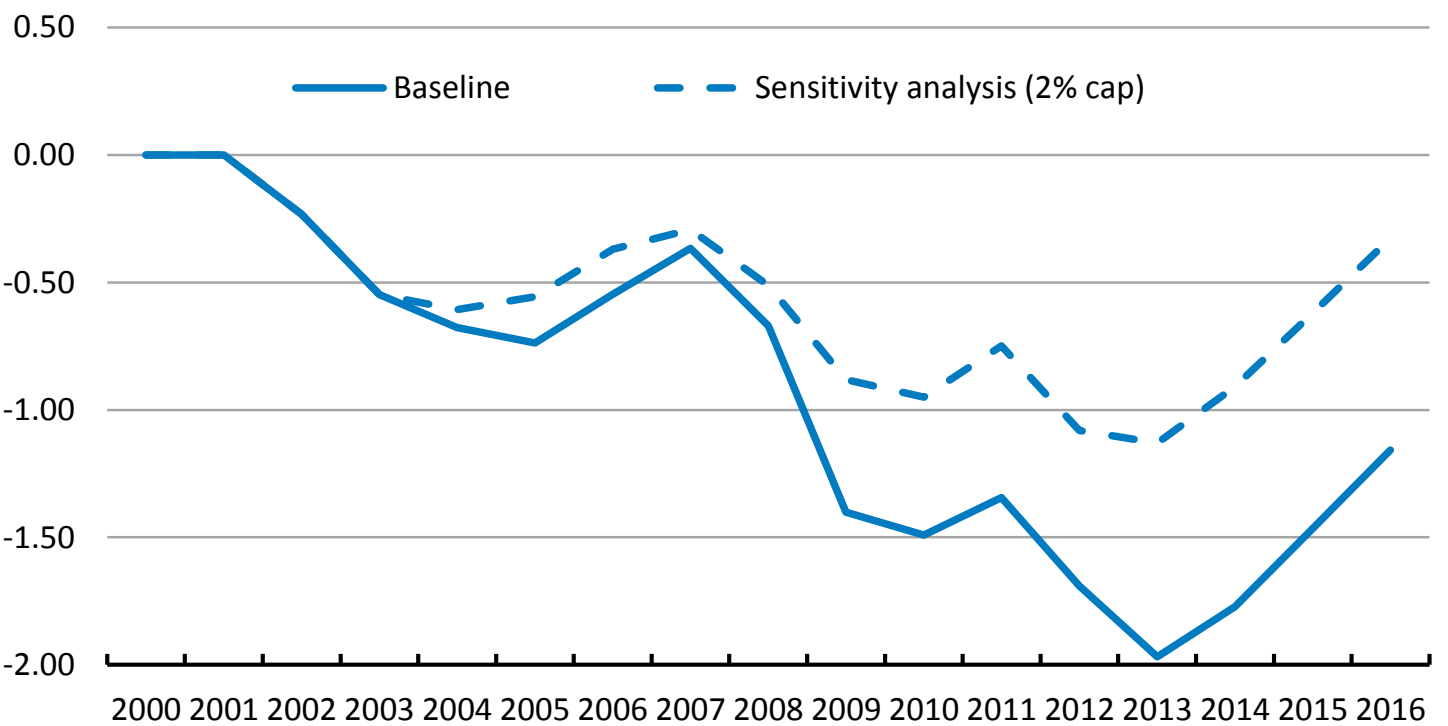

\footnotetext{
${ }^{1}$ Baseline refers to the specification laid out in the design section presented above i.e. with a $5 \%$ of GDP cap in country cumulative balances. Sensitivity analysis refers to a scenario where we impose a $2 \%$ cap instead, related to additional robustness analysis presented in the section on stabilisation.
}

\section{Country specific results: net transfers}

47. Annual net transfers for a given country consist in the difference between the pay-out it receives from the fund and the contribution it disburses to it. Table 7 shows annual net transfers country by country from 2000 to 2016 . 
Table 7. Net transfers to and from the unemployment benefit re-insurance scheme ${ }^{1}$ As per cent of GDP

AUT BEL DEU ESP EST FIN FRA GRC IRL ITA LUX LVA NLD PRT SVK SVN SUm of

\begin{tabular}{|c|c|c|c|c|c|c|c|c|c|c|c|c|c|c|c|c|c|}
\hline & AUI & Dㄷㄴ & UᄃU & CST & & rit & & & & IIA & LUג & LVA & IVLL & & & & transfers \\
\hline 2000 & 0.00 & 0.00 & & 0.00 & & 0.00 & 0.00 & & 0.00 & 0.00 & 0.00 & & 0.00 & 0.00 & & & 0.00 \\
\hline 2001 & 0.00 & 0.00 & & 0.00 & & 0.00 & 0.00 & & 0.00 & 0.00 & 0.00 & & 0.00 & 0.00 & & & 0.00 \\
\hline 2002 & 0.34 & 0.00 & 0.81 & 0.00 & & 0.00 & 0.00 & & 0.00 & 0.00 & 0.28 & & 0.00 & 0.00 & & & 0.23 \\
\hline 2003 & 0.30 & 0.00 & 1.04 & 0.00 & & 0.00 & 0.00 & & 0.00 & 0.00 & 0.75 & & 0.00 & 1.27 & & & 0.32 \\
\hline 2004 & 1.01 & -0.10 & 0.44 & -0.10 & & -0.10 & -0.10 & & -0.10 & -0.10 & 0.21 & & 0.73 & 0.22 & & & 0.14 \\
\hline 2005 & -0.09 & -0.02 & 0.43 & -0.10 & & -0.10 & -0.10 & -0.10 & -0.10 & -0.10 & 0.15 & & 0.07 & 0.73 & & & 0.07 \\
\hline 2006 & -0.30 & -0.15 & -0.30 & -0.10 & & -0.10 & -0.10 & -0.10 & -0.10 & -0.10 & -0.17 & & -0.20 & -0.18 & & & -0.17 \\
\hline 2007 & -0.30 & -0.15 & -0.30 & -0.10 & & -0.10 & -0.10 & -0.10 & -0.10 & -0.10 & -0.35 & & -0.20 & 0.04 & & & -0.16 \\
\hline 2008 & -0.20 & -0.05 & -0.20 & 3.02 & & 0.00 & 0.00 & 0.00 & 1.72 & 0.00 & -0.25 & & -0.10 & -0.25 & & & 0.31 \\
\hline 2009 & 0.90 & 0.79 & -0.30 & 2.25 & & -0.10 & 1.64 & -0.10 & 3.60 & -0.10 & 0.96 & & 0.50 & 1.53 & -0.10 & -0.10 & 0.70 \\
\hline 2010 & -0.35 & 0.22 & -0.30 & 0.00 & & 0.01 & -0.02 & 3.00 & 0.09 & 0.51 & -0.05 & & 0.39 & 0.94 & -0.10 & 1.27 & 0.12 \\
\hline 2011 & -0.35 & -0.25 & -0.30 & -0.05 & -0.10 & -0.15 & -0.20 & 2.17 & 0.14 & -0.07 & -0.45 & & -0.30 & 0.75 & -0.10 & 0.78 & -0.12 \\
\hline 2012 & -0.03 & -0.25 & -0.30 & -0.15 & -0.10 & -0.15 & 0.40 & -0.20 & -0.26 & 2.07 & -0.01 & & 0.55 & -0.21 & -0.10 & 0.48 & 0.33 \\
\hline 2013 & 0.12 & 0.66 & -0.25 & -0.09 & -0.10 & 0.34 & 0.28 & -0.25 & -0.35 & 1.18 & 0.28 & & 1.08 & -0.06 & 0.17 & 1.01 & 0.27 \\
\hline 2014 & -0.06 & -0.21 & -0.20 & -0.40 & -0.10 & 0.28 & -0.28 & -0.30 & -0.35 & 0.23 & -0.19 & -0.10 & -0.22 & -0.55 & -0.15 & -0.30 & -0.17 \\
\hline 2015 & -0.24 & -0.35 & -0.15 & -0.40 & -0.10 & 0.45 & -0.29 & -0.30 & -0.35 & -0.35 & -0.45 & -0.10 & -0.40 & -0.50 & -0.15 & -0.30 & -0.27 \\
\hline 2016 & -0.06 & -0.30 & -0.10 & -0.40 & -0.10 & -0.30 & -0.40 & -0.30 & -0.35 & -0.35 & -0.40 & -0.10 & -0.35 & -0.45 & -0.15 & -0.30 & -0.28 \\
\hline
\end{tabular}

${ }^{1}$ Positive numbers indicate payment from the fund to the country (positive net transfer) and negative numbers indicate payment from the country to the fund (negative net transfer)

${ }^{2}$ As a fraction of euro area GDP.

48. As can be seen, countries are alternatively net contributors and net recipient to the fund, to the exception of Estonia and Latvia which join the scheme in later years. For example, Germany would have benefited from positive transfers from 2002 to 2005, and then would have been a contributor due to trigger not activating again and experience rating kicking-in. In later years, as experience rating fades away, Germany would have seen its contribution decrease, for in the end an average net payment for the whole period of zero (see Figure 3). Austria would have had a similar profile (positive transfers in first part of the period until 2005, then contributions later, but on top of that it would have receive transfers in 2009 and again in 2013, for an average net transfer of $0.04 \%$ of GDP.

49. Most other countries (Belgium, France, Spain, Italy, Finland, and Greece) would not have triggered the fund until the 2008 crisis, making them contributors due to the start-stop mechanism since other countries would draw on the fund, before receiving positive transfers during crisis years. In the last few years of the study they would contribute again due to experience rating. Luxembourg, the Netherlands and Portugal switch between being net recipient and net contributor frequently during the whole period, as 
they alternate between years when they trigger support and others when they contribute through experience rating.

50. Portugal would have activated the fund most often (10 times, as Austria and Luxembourg) but overall experience rating ensures that ultimately it would have contributed to the fund in later years (at most $0.55 \%$ of GDP, the highest contribution in the sample), for an average net transfer of $0.19 \%$ of GDP. All average net transfers are close to zero for most countries, and for those with highest average (crisis countries), it stays below 1\% of GDP. At most, annual net transfers required from the countries are below $1 \%$ of GDP. Figure 3 shows the average as well as minimum and maximum net transfers. Unsurprisingly, the distributions are distorted towards higher maximum payments and positive average: the distribution of transfers, particularly for some countries such as Spain, Greece, or Ireland showing high maximum positive transfers reflects the reinsurance functioning of the scheme. Sizeable support is financed through modest contributions and borrowing, in exceptional circumstances. This shape could also be explained by the fact that two severe crises has occurred during the sample period, (Carnot, Kizior and Mourre, 2017).

Figure 3. Pay-outs can be significant at times, but the average net transfers are close to zero

As per cent of GDP

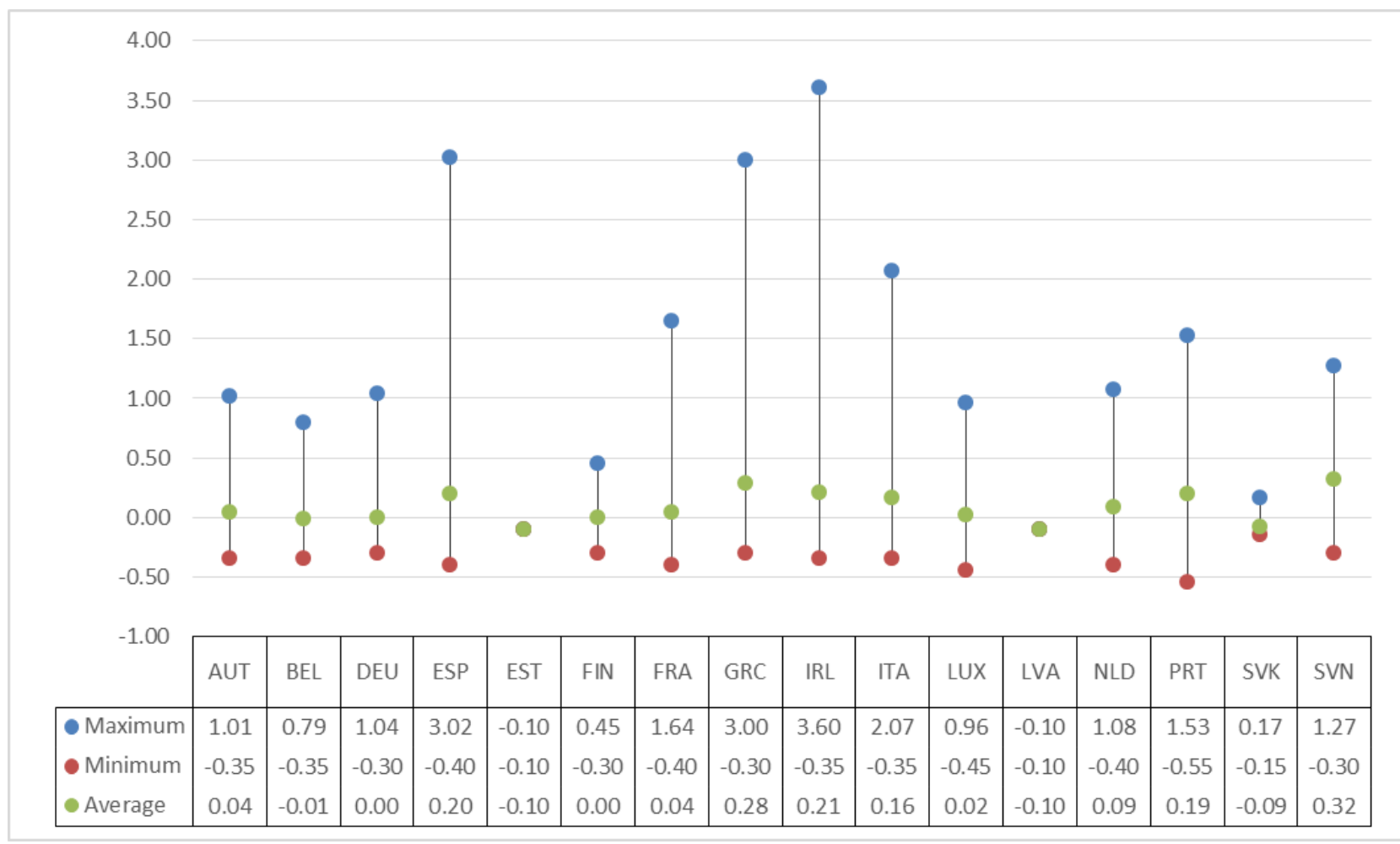

51. Given the parameters we selected, most countries run small positive cumulative positions, defined as the accumulation of net transfers over time. Put differently, they would obtain more pay-outs than they would pay contributions, which is consistent with the fund running debt and the sample period stopping in 2016 in the wake of the financial and the sovereign debt crises. There are few exceptions: Finland would have a small negative cumulative balance for most of the period but it would receive payouts towards the end and end up with a balance close to zero, so that it is not a permanent contributor. Estonia, Latvia and Slovak Republic have small negative cumulative balances but it should be noted that they are included in the scheme in later years at a time when they do not trigger support. 
52. Germany would end up with a negative net cumulative balance $(-0.22 \%$ of GDP) but after running a positive one from 2002 to 2014, and even the highest of all participating countries until 2007 (2.68\% at most). Most countries have contained cumulated positions well below 5\% of GDP, which do not excessively grow. However, for four countries (Greece, Ireland, Portugal, and Spain, those with the highest peaks in unemployment), the fund disburses significant one-time pay-outs. Hence, they build high net positive cumulative positions which bind the cap described in previous section, as can be seen in Figure 4, with a reversal at the end of the sample period. Because the period ends in 2016 at a time when these countries still have a high experience rating counter, their balance would eventually end up decreasing from these levels, which we cannot see from the graph. Figure 4 shows net cumulative balances for most countries. Overall, participating countries do not grow significantly high cumulative positions with respect to the fund. 
Figure 4. Cumulative net balances towards the fund remain contained

As per cent of GDP

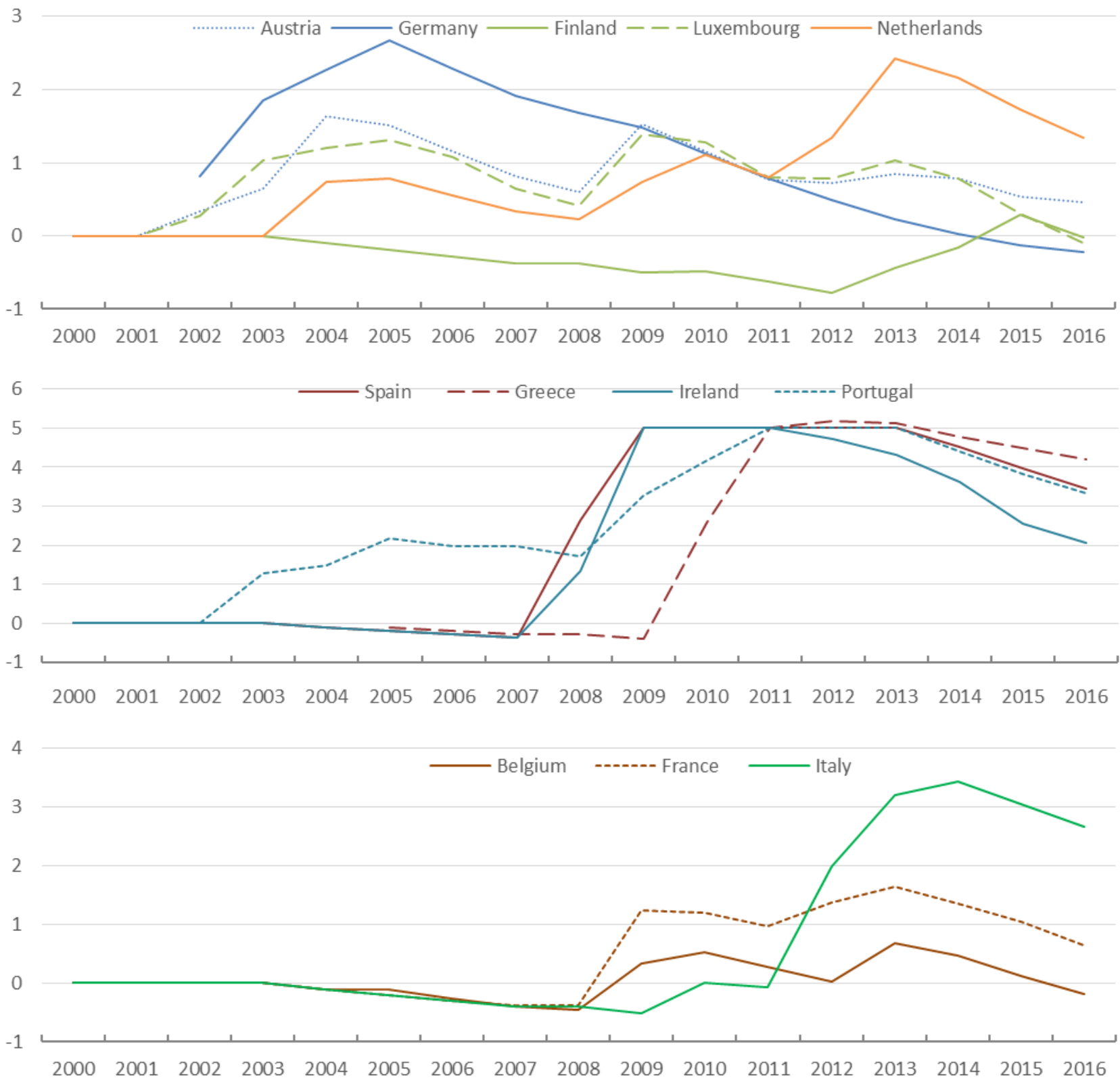

\section{Is the fund's activation timely?}

53. To assess the stabilization potential of the scheme, we compare the amount of net transfers it provides with variations in the unemployment rate, cyclical deficit (in per cent of GDP) and the real GDP growth rate, for the euro area and the member countries (Figure 5). We expect that for the EURS to be effective given its design, positive net transfers should be provided in times of severe crisis translating into drops in GDP and hikes in the unemployment rate, in amounts significant enough to compare with rises in cyclical component of the deficit. Cyclical component of the deficit is obtained from the AMECO database. Although it suffers from revisions and measurement errors and does not truly reflect fiscal stress put on unemployment agencies which the EURS aims at supporting, it appears to be a relevant metric to 
assess if the central scheme would behave in a counter-cyclical manner and assist national automatic stabilizers at the right time.

54. First, we observe that the unemployment rate is an appropriate indicator for the trigger mechanism, given its close correspondence to the cycle. Periods when it rises are in general also those of recession in terms of drops in real GDP. It is also when support is triggered (countries receiving net transfers): it is the case, for example, for Germany and Portugal in 2003, then for most countries in 2008 and 2009 (Austria, Spain, Ireland, France and Luxembourg for instance), and also in 2011 and 2012 (Greece, Italy, Netherlands).

Figure 5. Support for member countries is triggered in a timely fashion ${ }^{1}$

\section{A. Germany}
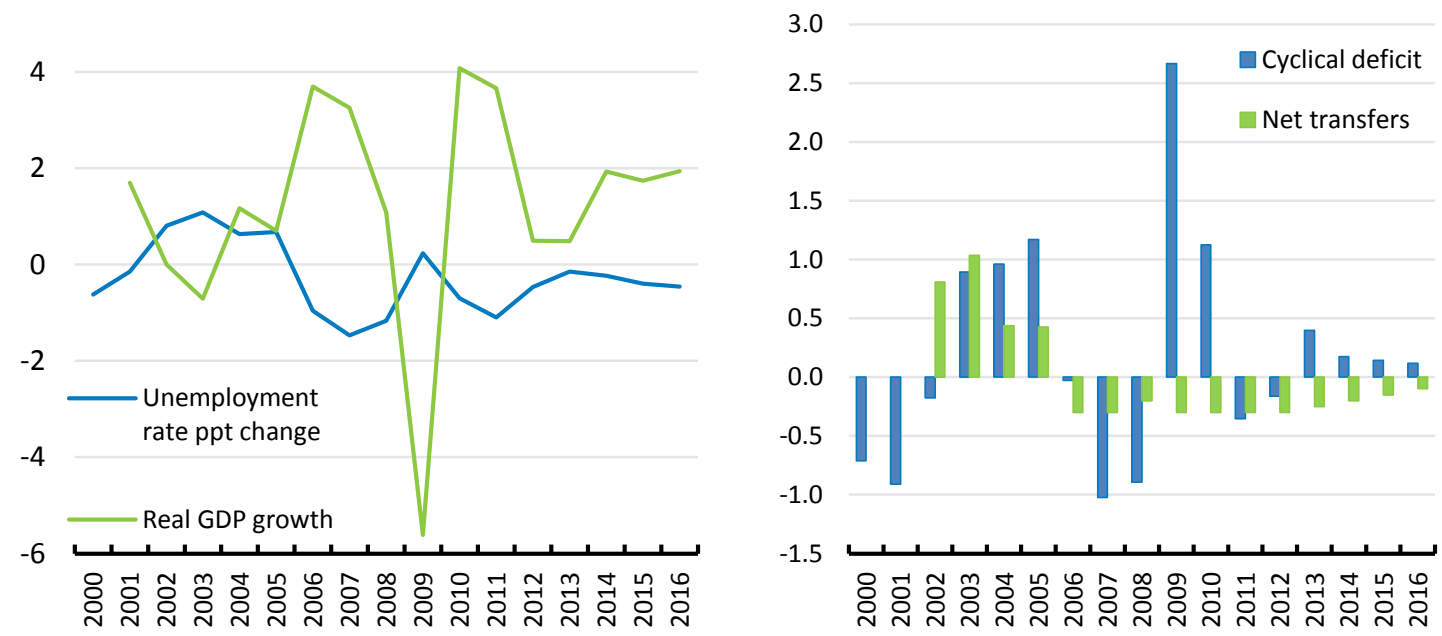

\section{B. France}
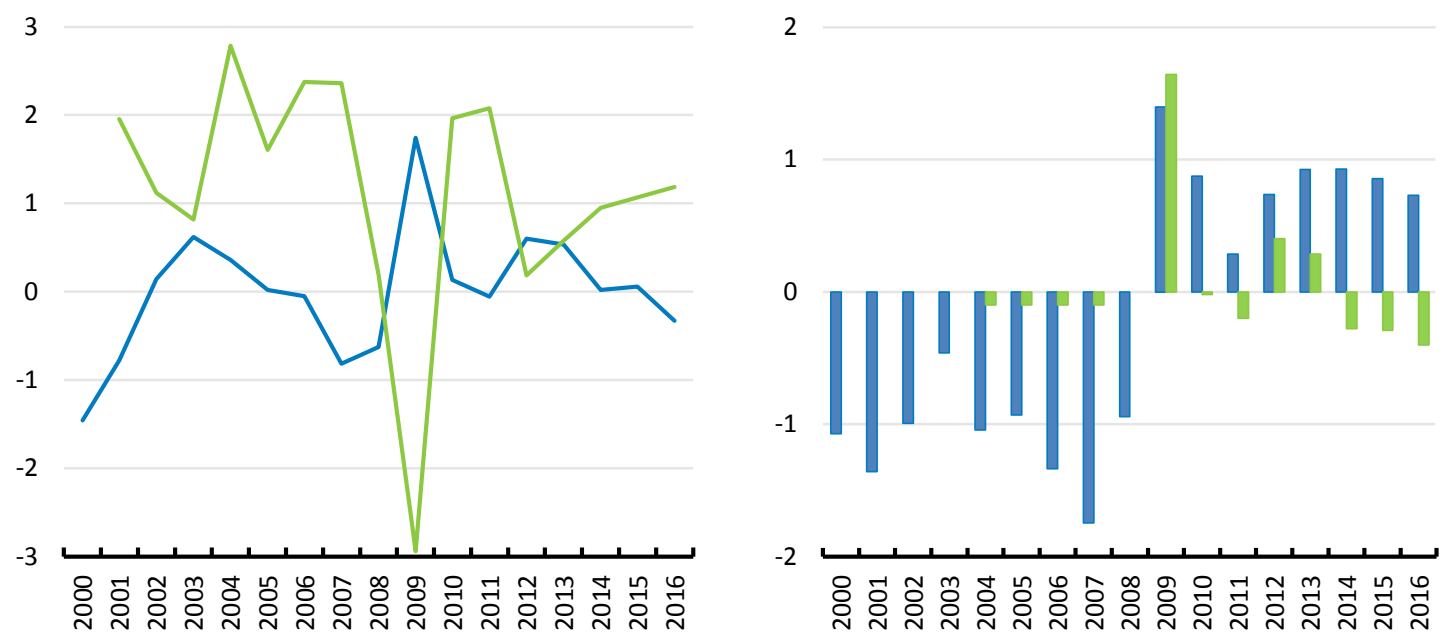


\section{Italy}
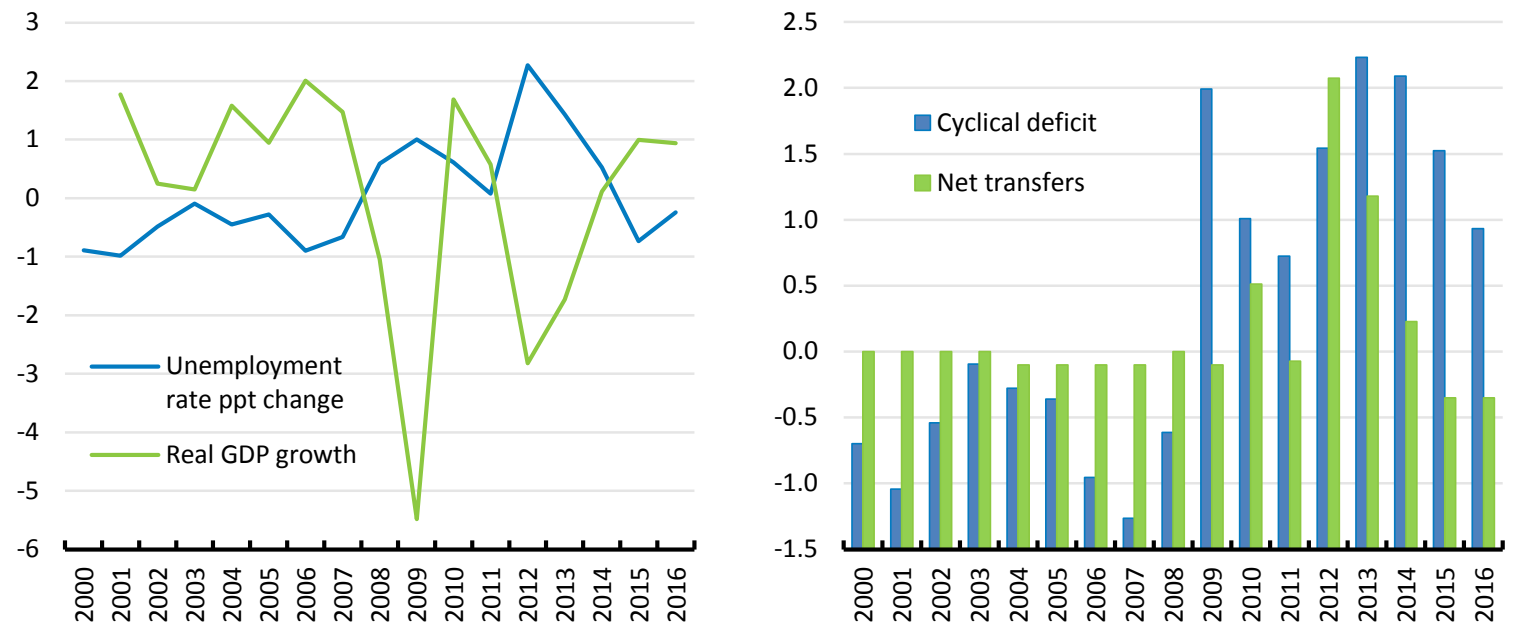

D. Spain
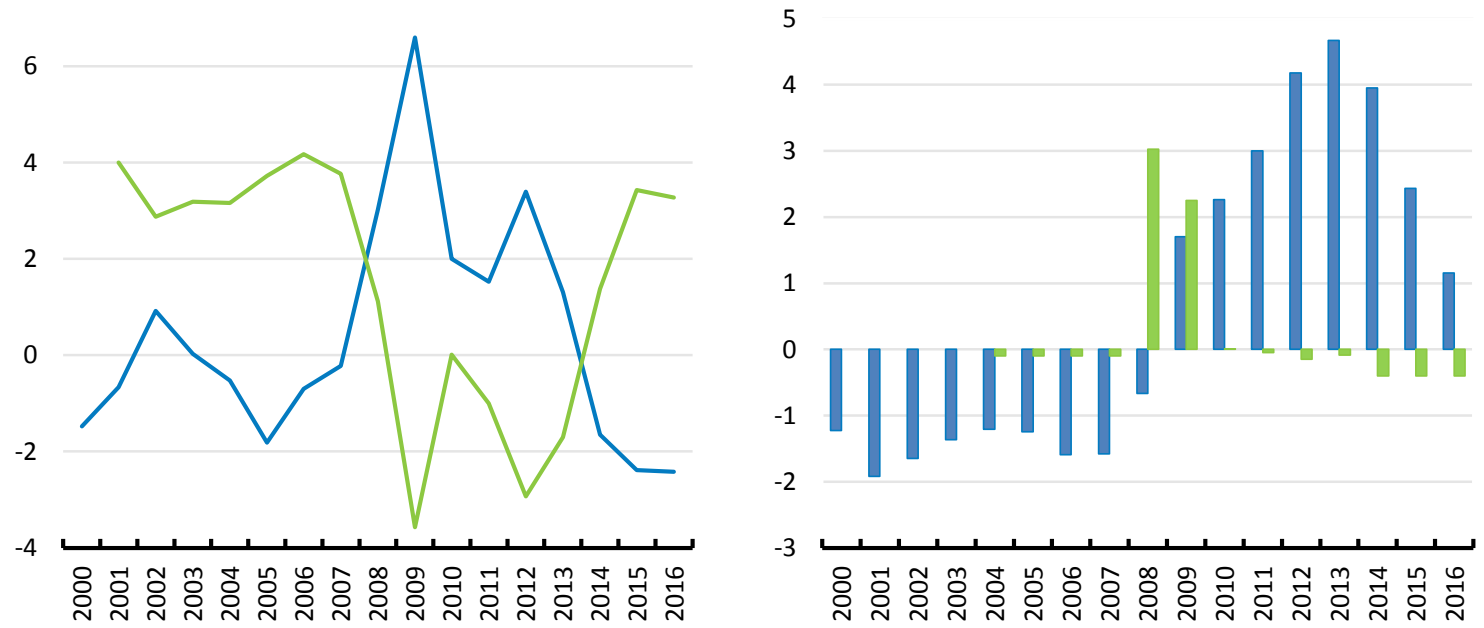

${ }^{1}$ Annual net transfers are expressed as a fraction of GDP and calculated as a difference between the sum of all country's pay-outs and contributions. Cyclical deficit in per cent of GDP is obtained from the AMECO database. Change in the unemployment rate is calculated as the year-on-year percentage point deviation from the rolling 10-year average. Real GDP growth rate is the year-on-year percent change of real GDP compared to previous year.

55. Conversely, in periods when the real GDP growth is positive, the fund is either inactive and net transfers are close to zero, or it collects contributions. This is consistent with the reinsurance logic of the fund, only activating when crisis hits, and then collecting contributions. As long as there is no experience rating and the fund is not indebted, there is no extra cost in times of growth or of cyclical surpluses.

56. The EURS also steps-in when pressure on public finances is the highest, when measured with the cyclical deficit. This is because periods when the unemployment rate increases (triggering support) are also times of rising cyclical component of the public deficit. Belgium and France in 2012 and 2013 are fitting examples. The amount of support is also of the same order of magnitude as shifts in GDP and cyclical deficits, so it seems our calibration implies sizeable enough transfers to face crises. For most countries, net positive transfers, increases in the unemployment rate and cyclical deficits in per cent of GDP are of comparable size, although transfers have lower amplitude since the EURS does not cover the entirety of shocks, due to the trigger logic and the cap on country cumulative balances. 
57. This pattern is observable at the euro area level (Figure 6). At the beginning of the period from 2002 to 2004, some positive net transfers are provided as euro area GDP growth decelerates and the aggregate unemployment rate rises: this is mostly due to Germany experiencing a small recession. The fund's deficit is then reduced and net transfers are negative, at a time when the unemployment rate decreases. As the financial crisis unfolds in 2008 with a drop in real GDP and big increases in the unemployment rate, high pay-outs in per cent of euro area GDP are provided. At most, the sum of net transfers amounts to $0.7 \%$ of GDP in 2009 , while the euro area deficit reached its peak at $1.89 \%$. Let us note as a comparison that in 2010, euro area countries spent on average $1.56 \%$ of GDP in social expenditure in unemployment (Table 4). Then, sizeable support is provided from 2011 to 2013 during the sovereign debt crisis, when the euro area unemployment rate and deficit increases again. Approaching the end of the period (from 2014 to 2016), when growth switches back to positive levels, net transfers are negative as countries contribute in net terms to the EURS (since the trigger stops support and experience rating kicks-in), at the same time that the cyclical deficit winds down. Hence, the fund's activity follows a counter-cyclical behaviour, complementing national fiscal policies from central level. Indeed, years of severe crisis are those with a high unemployment hike, itself translating into rising deficit which is when the EURS is activated.

Figure 6. The scheme's activation at the euro area level is timely ${ }^{1}$
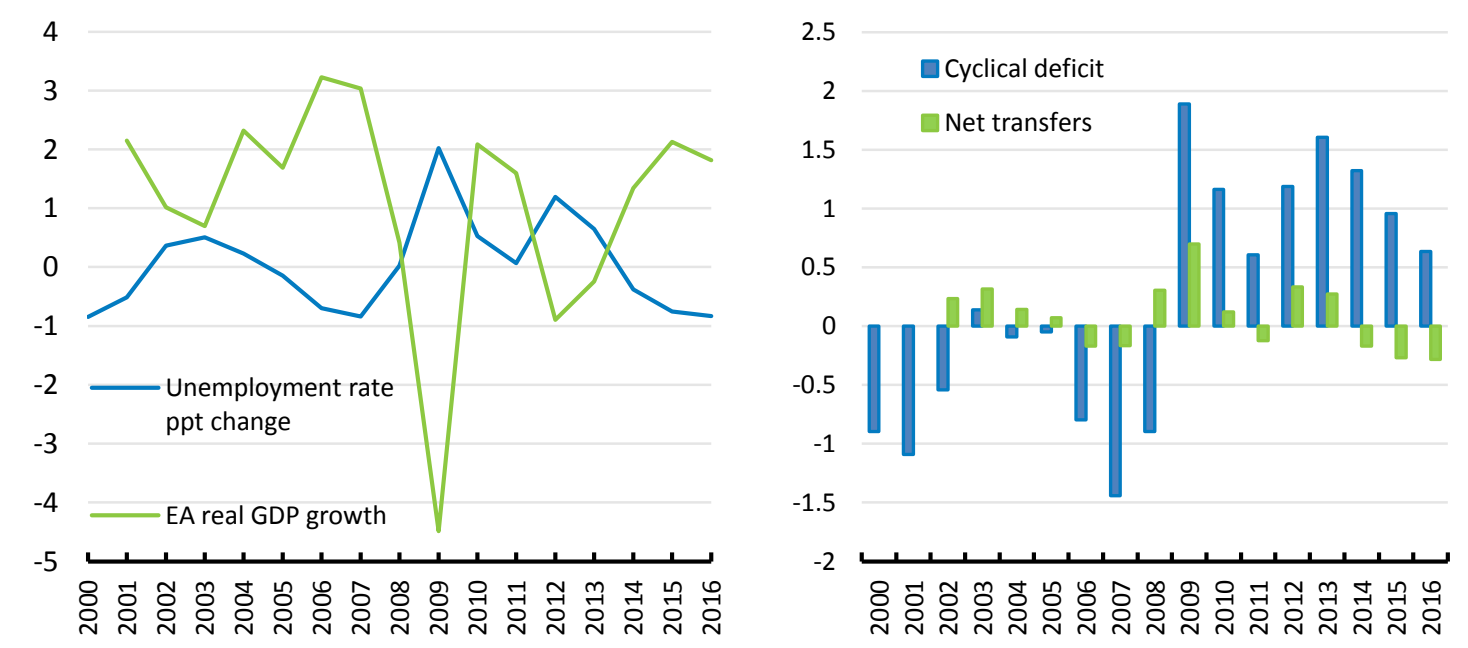

\begin{abstract}
${ }^{1}$ Annual net transfers are expressed as a fraction of GDP and calculated as a difference between the sum of all country pay-outs and contributions. Cyclical deficit in per cent of GDP is obtained from the AMECO database. Change in the unemployment rate is calculated as the year-on-year percentage point deviation. Real GDP growth rate is the year-on-year percent deviation of real GDP compared to previous year.
\end{abstract}

58. However, the country-by-country analysis reveals few cases where the scheme functions more poorly. There would be no pay-out in 2009 for Germany although it experienced a 5.62\% annual decline in real GDP and the cyclical deficit rose to $2.67 \%$ of GDP. This is because it did not translate into a harsh rise in unemployment, and hence the crisis would not trigger the reinsurance. This could be a design flaw for the scheme, as whether or not countries would be supported would depend on national policy: if it is such that unemployment does not rise, it might not receive pay-outs. The scheme would also somewhat penalise countries more flexible at the intensive margin rather than at the extensive margin, since in these countries a crisis would not translate into a rise in the unemployment rate but rather into within-firm adjustments. However, in our set-up, the reinsurance is one of unemployment benefits. So for countries where a recession does not lead to strong increases in the unemployment rate, the distress on public finances is coming from elsewhere. So pay-outs from the EURS are also less warranted, and the opportunity cost of not triggering support more limited. It stems from having a system reinsuring unemployment benefits where the reinsurance is triggered based on the unemployment rate as an indicator. 
59. Finally, years of recession (in terms of GDP growth), when unemployment and cyclical deficit are rising but net transfers do not increase, are due to the cap on cumulative balances binding. It can be seen for Spain, Portugal, Ireland and Greece in 2012 and 2013 and it is due to these countries receiving substantial pay-outs the previous years. This is suboptimal, as these countries would benefit from support during those years. However, there is a compromise to be made between the stabilization potential of the scheme and avoiding permanent transfers and substantially high positive balances, which could undermine the scheme's political credibility. For example, without the cap, Greece and Spain would have ended the simulation period with a cumulative balance of $17 \%$ and $15 \%$ of their GDP, respectively. We conduct a robustness check analysis regarding this cap in the following section.

\section{Quantifying stabilisation}

60. In order to assess macroeconomic stabilisation provided by the scheme, we calculate for each year a counterfactual GDP figure, equal the actual GDP observed plus the annual net transfer from the scheme, and compare it to the actual GDP. As there is no earmarking of spending in our baseline specification, we apply a fiscal multiplier of unity to the net transfer.

61. Our analysis suggests potentially strong stabilization properties, based on moderate contributions (Figure 7 and 8). At the scale of the euro area, the counterfactual growth rate is higher than the actual rate from 2001 to 2005 as countries such as Germany and Austria would have received transfers, before being lower due to net contributions from most countries in 2006 and 2007. With significant support provided in 2009 , counterfactual GDP is $0.7 \%$ higher than the actual GDP. The scheme would have activated again in 2012 and 2013, before charging contributions towards the end of the period. Overall, the EURS reduces, through counter-cyclical action, the standard deviation of EA real GDP growth rate by $0.24 \%$ from 2009 to 2013 , from $2.33 \%$ to $2.09 \%$ (roughly a $10 \%$ reduction). From 2000 to 2016, the EURS reduces it by $0.2 \%$, from $1.8 \%$ to $1.6 \%$ (an $11 \%$ reduction).

Figure 7. The EURS would deliver significant stabilisation for the euro area

Euro area real GDP growth

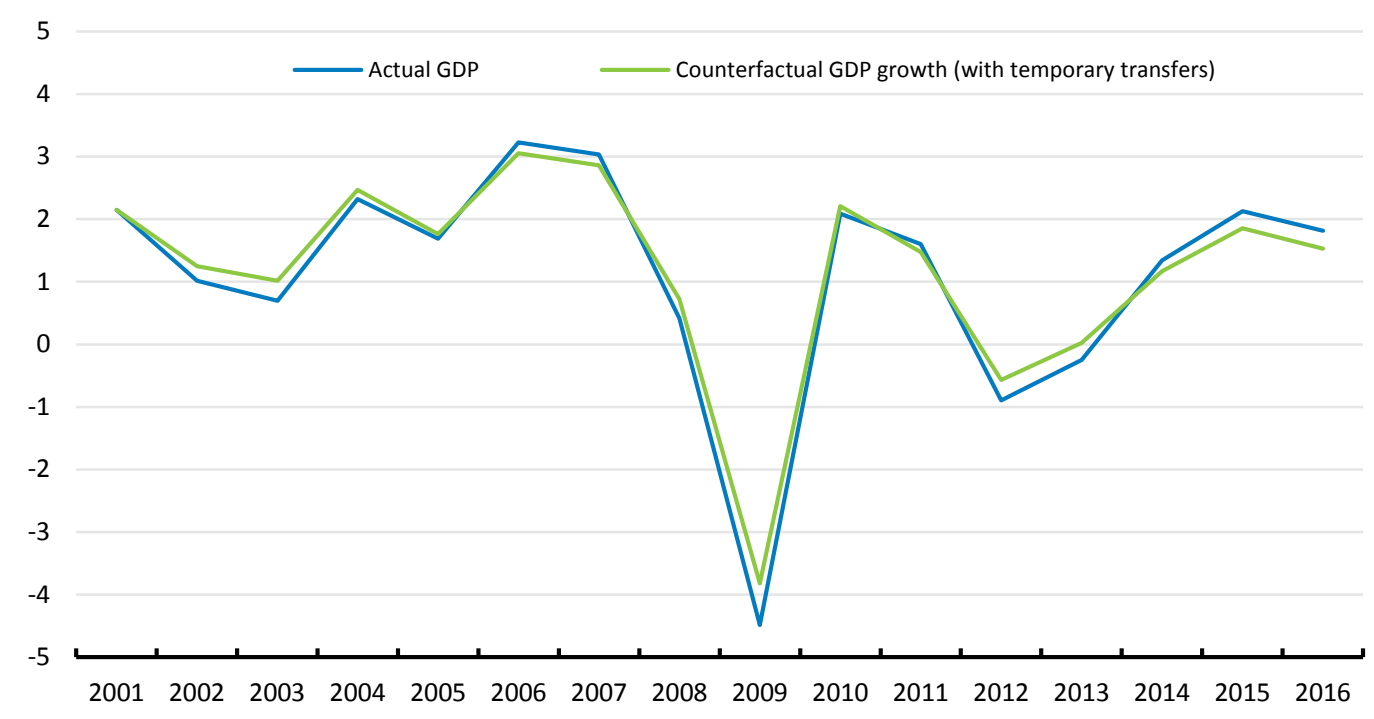

62. From the viewpoint of countries, the scheme provides stabilizing support in times of crisis and charges contributions in the following years, in a counter-cyclical fashion. Looking at the counterfactual 


\section{ECO/WKP(2018)45}

simulation data, the unemployment benefit re-insurance scheme would reduce standard deviation of the real GDP growth rate from 2000 to 2016 for all countries (Table 8).

Table 8. The scheme would reduce the standard deviation of real GDP growth

\begin{tabular}{|c|c|c|c|c|c|c|c|c|c|c|c|c|c|c|c|c|c|}
\hline & AUT & BEL & DEU & ESP & EST & FIN & FRA & GRC & IRL & ITA & LUX & LVA & NLD & PRT & SVK & SVN & EA \\
\hline $\begin{array}{c}\text { Reduction in } \\
\text { the standard } \\
\text { deviation of } \\
\text { real GDP } \\
\text { growth, } \\
2000-2016\end{array}$ & $-0,16$ & $-0,15$ & $-0,06$ & $-0,17$ & 0,00 & $-0,04$ & $-0,34$ & $-0,46$ & $-0,49$ & $-0,17$ & $-0,17$ & 0,00 & $-0,19$ & $-0,12$ & $-0,05$ & $-0,30$ & -0.20 \\
\hline
\end{tabular}

Figure 8. The scheme would improve stabilisation country by country
A. Germany
B. France

5
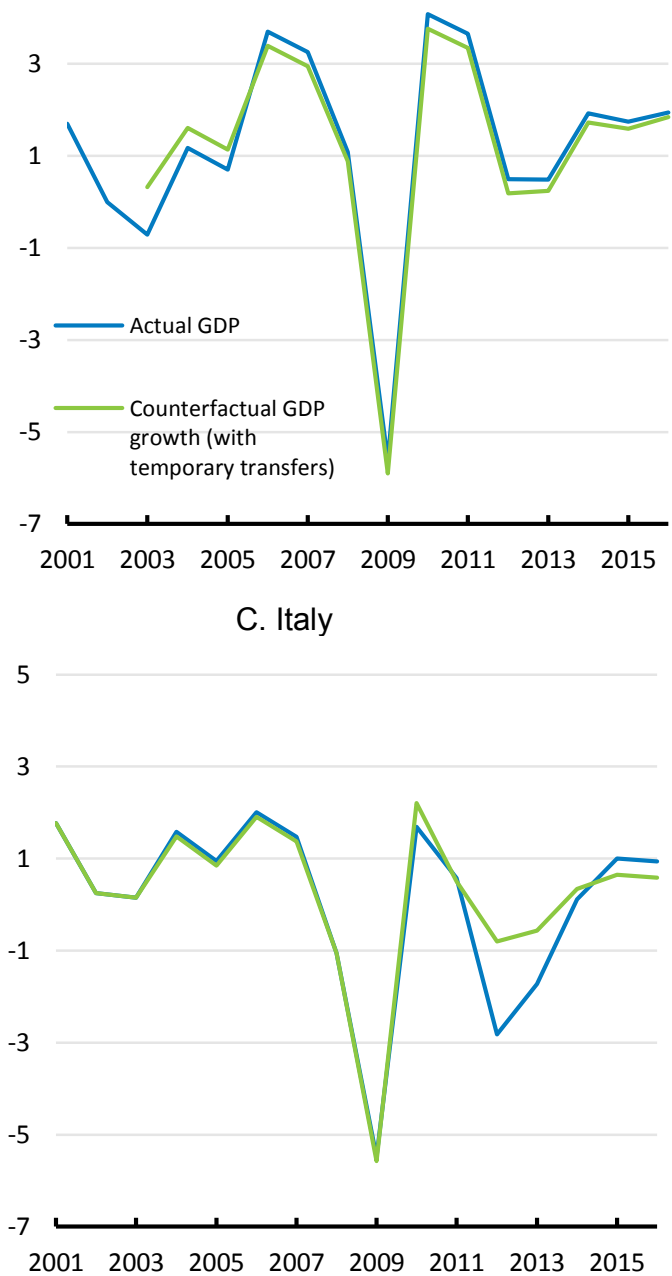

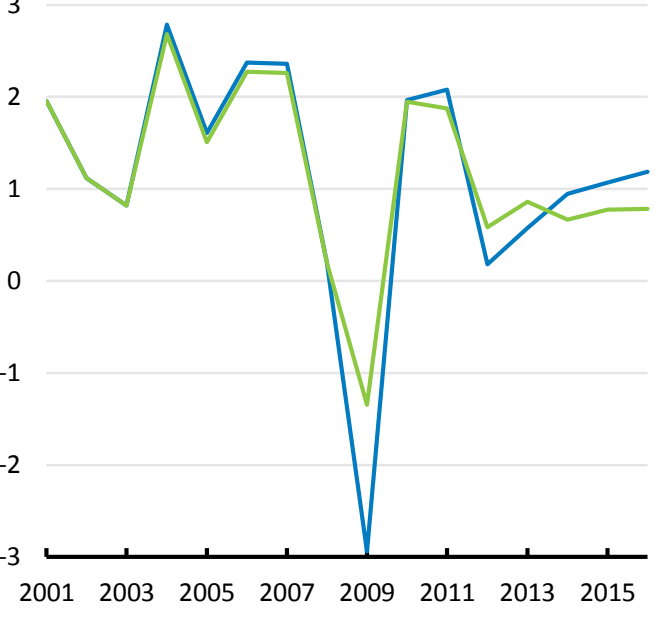

D. Spain

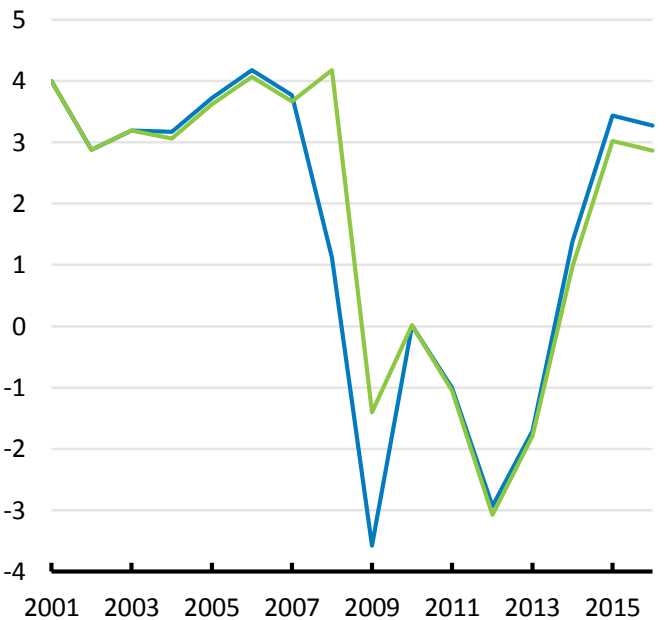

63. It should be noted that untimely payments (when the fund charges net negative transfers to a country while it is in a year of negative growth) occur in $7.6 \%$ of cases, but only in small amounts. It happens in some years, in which the countries stop triggering pay-outs but pay experience rating, and it stems from design features aiming at preventing permanent transfers. 
64. As a robustness check, we assess the stabilisation potential of the scheme by applying a multiplier of 1.5 to the annual net transfers (before adding or subtracting the net transfer to or from the observed annual GDP). Indeed, our baseline specification assumes no earmarking, but in principle the support from the scheme could yield additional stabilisation, should the transfers be channelled to support items with high fiscal multiplier, such as unemployment benefits. Deciding on a multiplier for unemployment benefits is not trivial and subject to an extensive literature. We select the estimate of 1.5, which strikes a balance between existing studies; see the overview in Beblavý et al. (2015). This approach leaves aside any general equilibrium effect and relies on a simple calculation, but it gives a general idea for the amount of stabilization if we assume a multiplier higher than one.

65. Counterfactual analysis shows that with a multiplier of 1.5 , the scheme would have reduced the standard deviation of the euro area real GDP growth rate by $0.36 \%$, from $2.33 \%$ to $1.97 \%$ (a $15 \%$ reduction against $10 \%$ in our baseline). For the whole sample period, the scheme would have reduced it by $0.3 \%$, from $1.8 \%$ to $1.5 \%$ (a $16 \%$ reduction against $11 \%$ in the baseline). Standard deviation of real GDP growth would be reduced further than the baseline case, again for all countries (Table 9). Of course, the stronger stabilisation effect compared to our baseline scenario is driven by the assumption of a higher multiplier, while the counter-cyclical interventions of the scheme are the same as before, since the functioning of the trigger, pay-outs and contributions are not impacted. We conclude that the scheme does not rely on the assumption of a multiplier higher than one, in order to improve macroeconomic stabilisation, both from a country-specific or area-wide perspective. The stabilisation power of the scheme rather builds on careful design features ensuring timely and effective activation.

Table 9. Reduction of the standard deviation of real GDP growth with a multiplier of $\mathbf{1 . 5}$

\begin{tabular}{|c|c|c|c|c|c|c|c|c|c|c|c|c|c|c|c|c|c|}
\hline & AUT & BEL & DEU & ESP & EST & FIN & FRA & GRC & IRL & ITA & LUX & LVA & NLD & PRT & SVK & SVN & EA \\
\hline $\begin{array}{l}\text { Reduction in } \\
\text { the standard } \\
\text { deviation of } \\
\text { real GDP } \\
\text { growth, 2000- } \\
2016\end{array}$ & -0.20 & -0.20 & -0.07 & -0.12 & 0.00 & -0.05 & -0.46 & -0.60 & -0.69 & -0.19 & -0.24 & 0.00 & -0.24 & -0.10 & -0.08 & -0.37 & -0.30 \\
\hline
\end{tabular}

66. We conduct additional sensitivity analysis by capping the country cumulative balances towards the fund at $2 \%$ of GDP (instead of the baseline 5\%). As a result, the cap becomes binding for more countries, including Germany in 2004 and 2005 and the Netherlands in 2013. For countries where the 5\% cap is already binding, the introduction of the $2 \%$ cap reduces the pay-outs they receive. Hence, the total amount of the scheme's support for the whole period decreases to $0.18 \%$ of GDP (compared to the baseline support of $0.25 \%$ ) and the amount of debt issued by the scheme decreases (Figure 2). At most, the scheme would be indebted by $1.13 \%$ of euro area GDP (compared to $1.97 \%$ of euro area GDP in the baseline).

67. The drawback of the lower cap would be reduced stabilisation. The reduction in real GDP standard deviation for the euro area would be $0.13 \%$ for $2000-2016$ (compared to $0.2 \%$ in the baseline) and $0.14 \%$ for $2009-2013$ (compared to $0.24 \%$ in the baseline). Since the 5\% cap already ensures that country cumulative balances towards the fund are limited, the benefits of the $2 \%$ cap, given the worsened stabilisation properties, appear limited. From a country-by-country perspective, the $2 \%$ cap leads to smaller reductions in real GDP standard deviation, especially in the former crisis countries, while the standard deviation even increases in Spain (Table 10). 


\section{ECO/WKP(2018)45}

Table 10. Reduction of the standard deviation of real GDP growth with a $2 \%$ GDP cap on scheme's support

\begin{tabular}{|c|c|c|c|c|c|c|c|c|c|c|c|c|c|c|c|c|c|}
\hline & AUT & BEL & DEU & ESP & EST & FIN & FRA & GRC & IRL & ITA & LUX & LVA & NLD & PRT & SVK & SVN & EA \\
\hline $\begin{array}{l}\text { Reduction } \\
\text { in the } \\
\text { standard } \\
\text { deviation of } \\
\text { real GDP } \\
\text { growth, } \\
\text { 2000-2016 }\end{array}$ & $-0,15$ & $-0,14$ & $-0,06$ & 0,02 & 0,00 & $-0,03$ & $-0,33$ & $-0,11$ & $-0,26$ & $-0,10$ & $-0,16$ & 0,00 & $-0,16$ & $-0,05$ & $-0,05$ & $-0,02$ & -0.13 \\
\hline
\end{tabular}

68. Finally, our simulations suggest that a scheme without a cap would reduce the standard deviation of real GDP growth in the euro area for the period $2000-2016$ by $0.3 \%$, compared to $0.2 \%$ in our baseline. However, without a cap, some countries would run significantly higher balances vis-à-vis the unemployment benefit re-insurance scheme, potentially undermining the credibility of the commitment to avoiding permanent transfers. Given the relatively limited difference in macroeconomic stabilisation properties between a 5\% cap and no cap, it seems that an unemployment benefit reinsurance scheme with a $5 \%$ cap on country-specific balances strikes the right balance between political feasibility and macroeconomic stabilisation.

\section{Conclusion}

69. The paper studies a version of a euro area central fiscal capacity, in the form of a European unemployment re-insurance scheme. Careful design can result in potentially high stabilisation effects, based on modest contributions and limited debt issuance. In the simulation period from 2000 to 2016, the trigger mechanism would make the scheme's activation timely, when unemployment and cyclical deficits peak, and support would be significant enough to alleviate large crises. With an average contribution of $0.17 \%$ of GDP and debt issuance below $2 \%$ of the euro area GDP, the scheme would reduce the standard deviation of the real GDP growth rate in the euro area between 2000 and 2016 by $0.2 \%$. This would be achieved without the occurrence of permanent transfers, as experience rating ensures that countries are alternatively contributors and recipients, while cumulative country balances with the fund capped by design below $5 \%$ of GDP. 
ECO/WKP(2018)45

\section{APPENDIX}

Figure A.1. Support for member countries is triggered in a timely fashion ${ }^{1}$

\section{A. Austria}
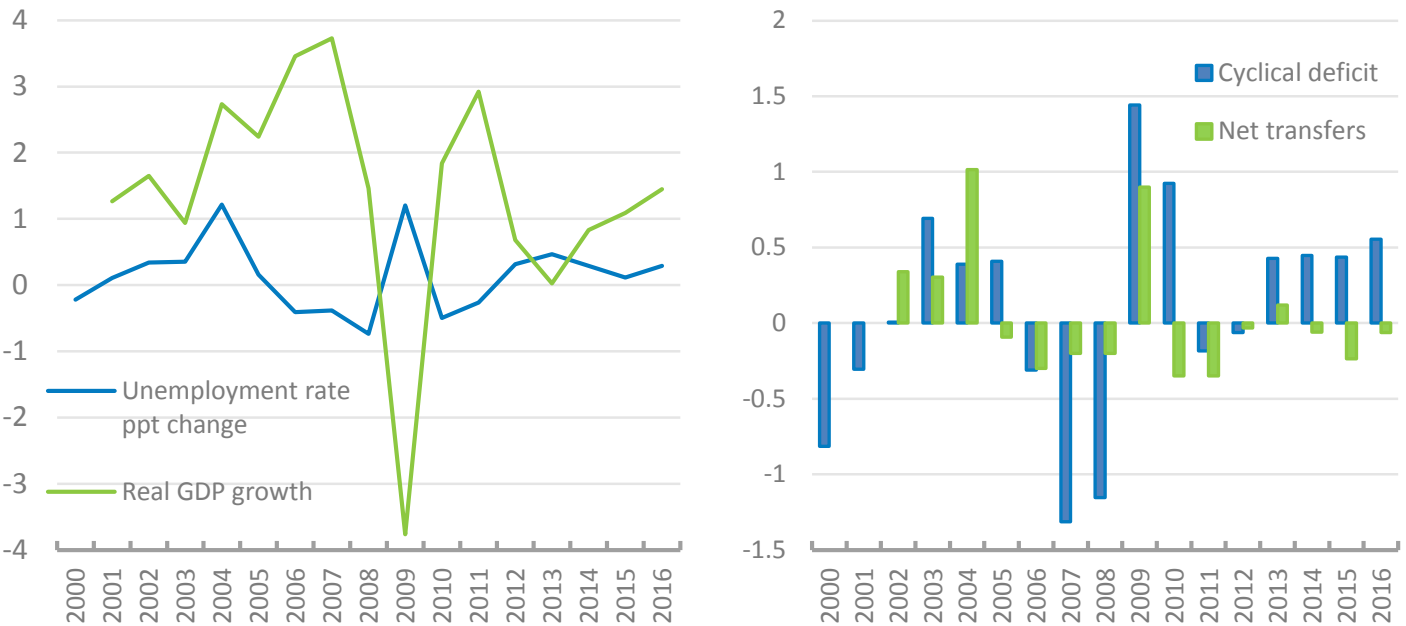

B. Belgium
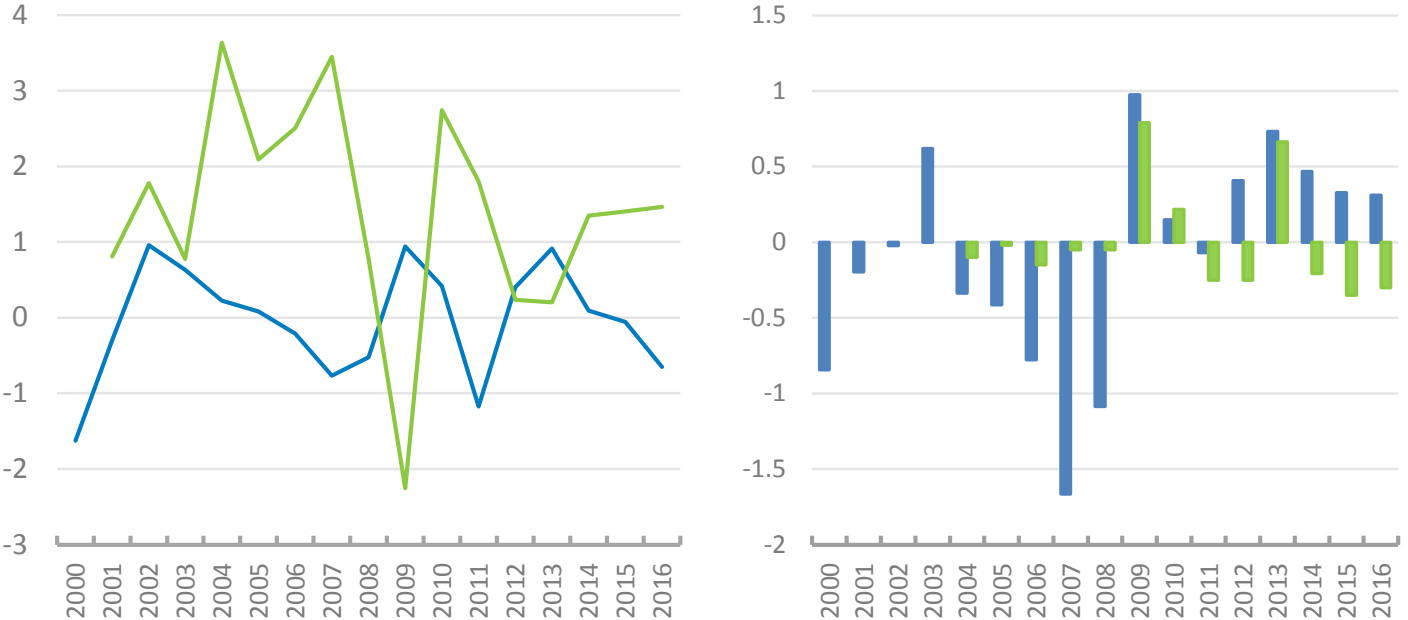


\section{Estonia}

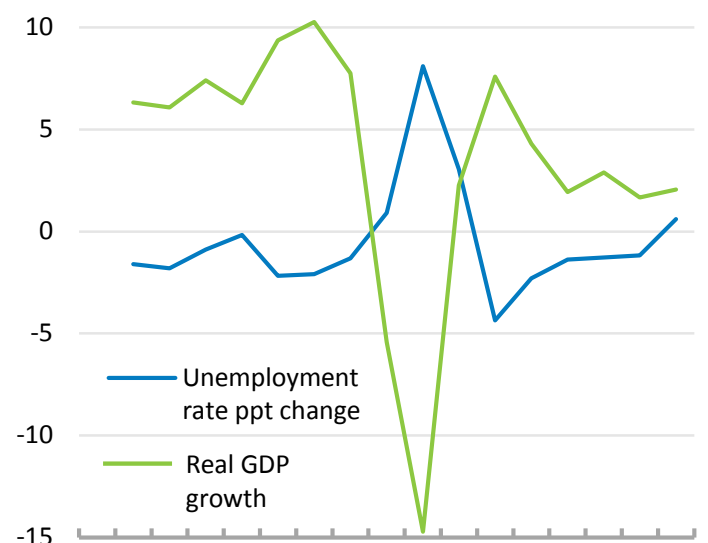

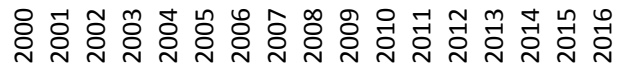

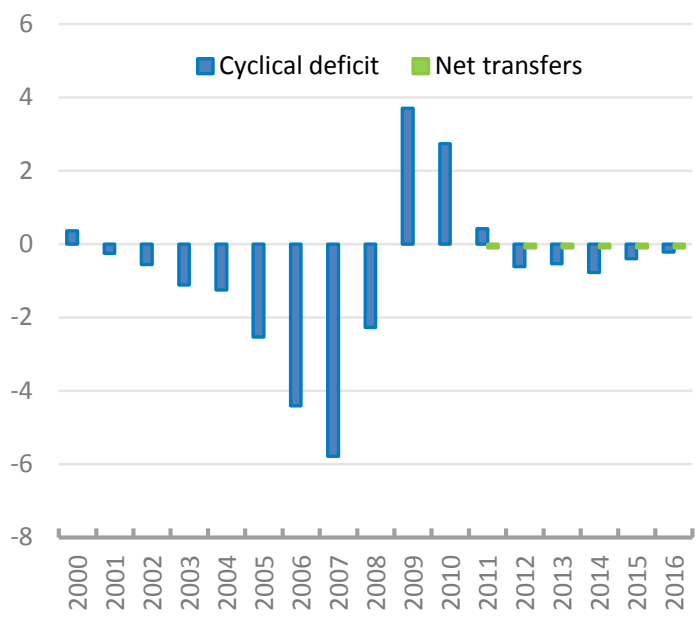

D. Finland

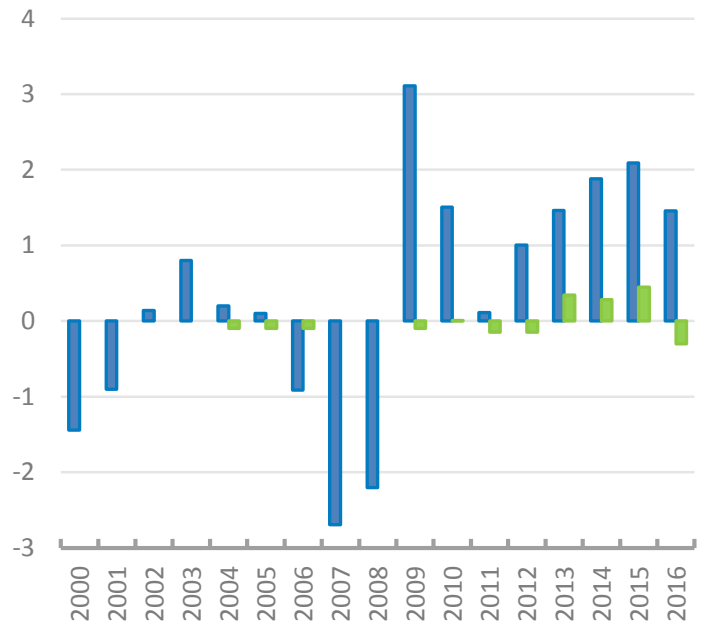

E. Greece

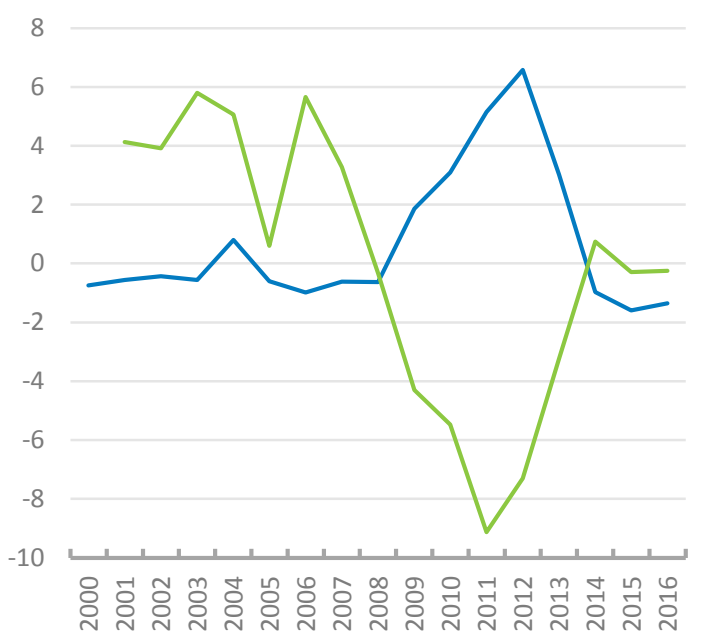



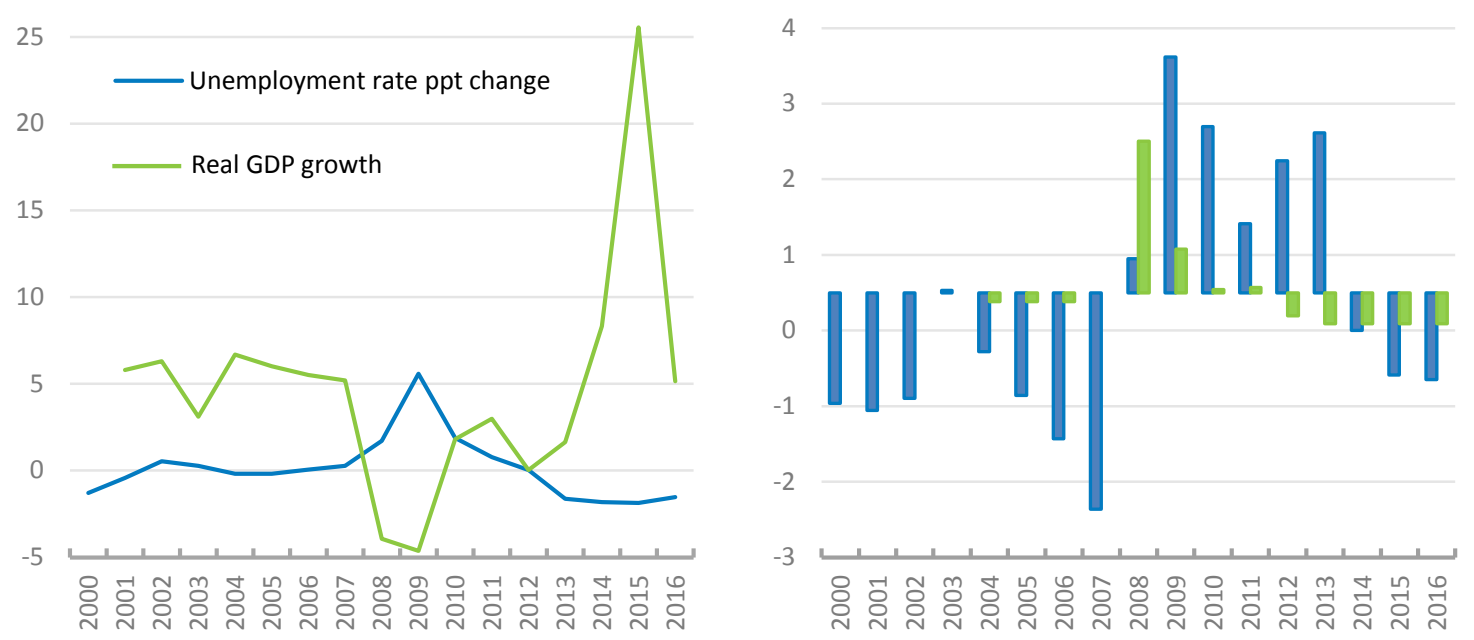

\section{G. Latvia}
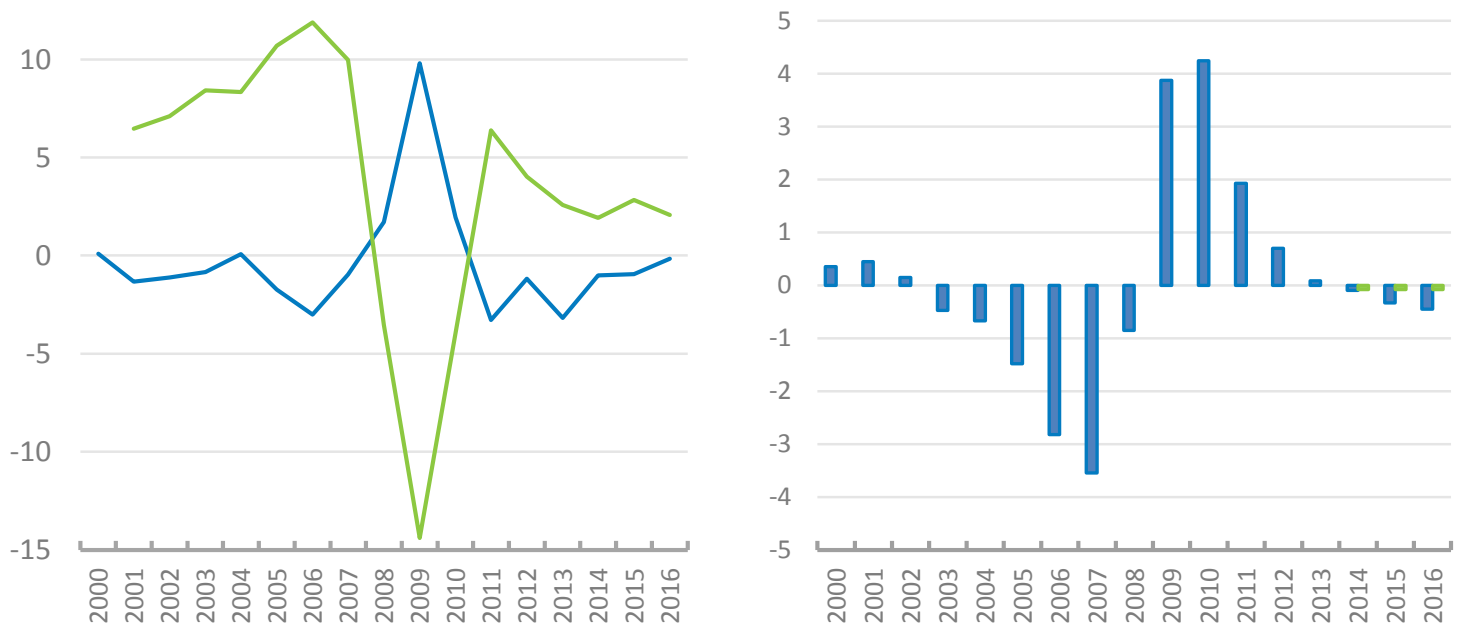

\section{H. Luxembourg}
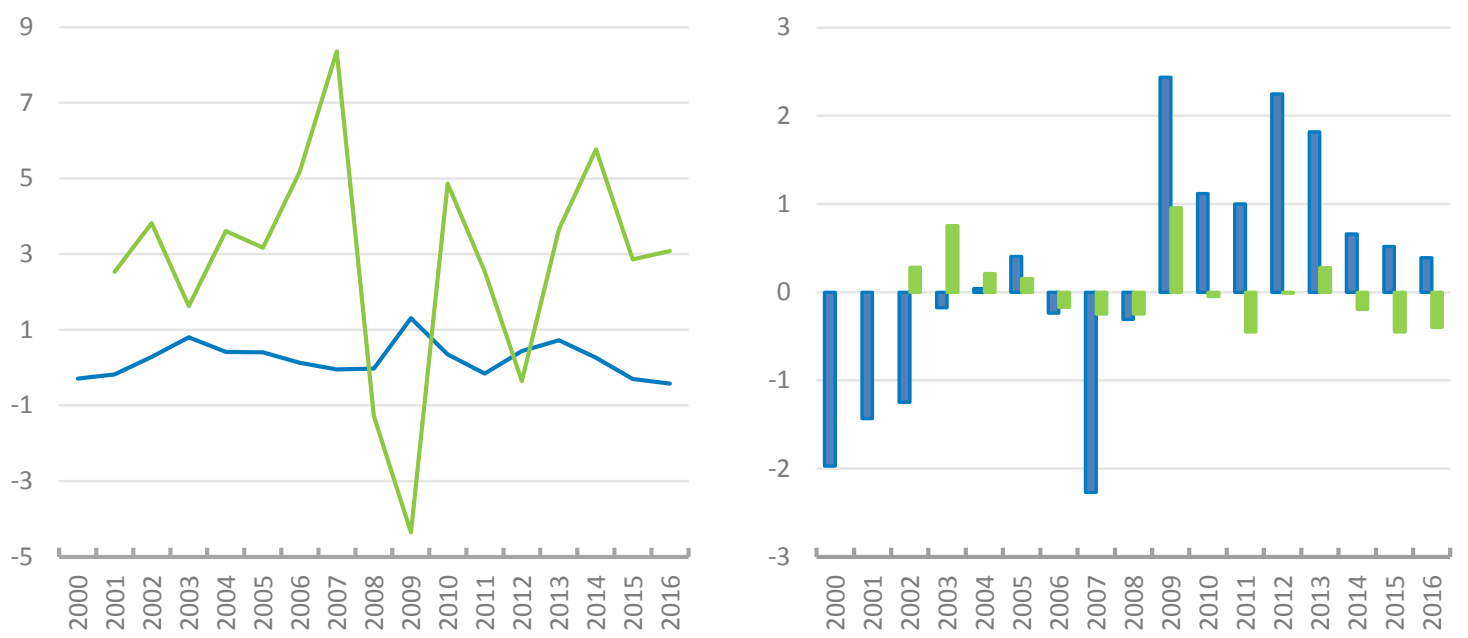
I. the Netherlands

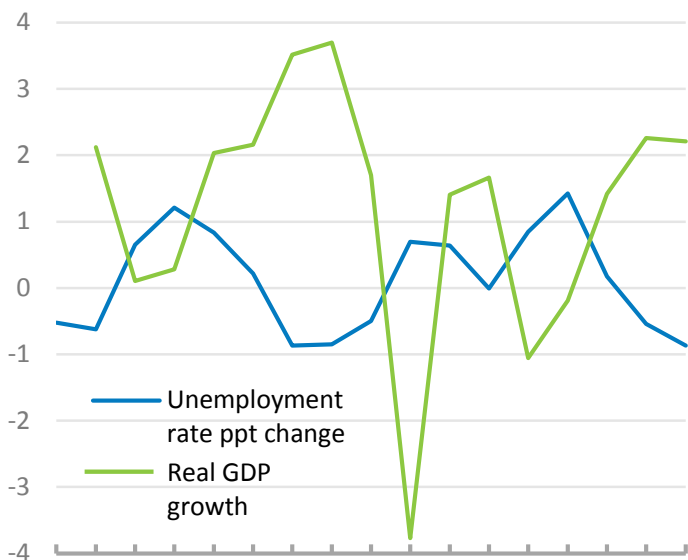

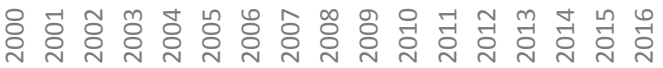

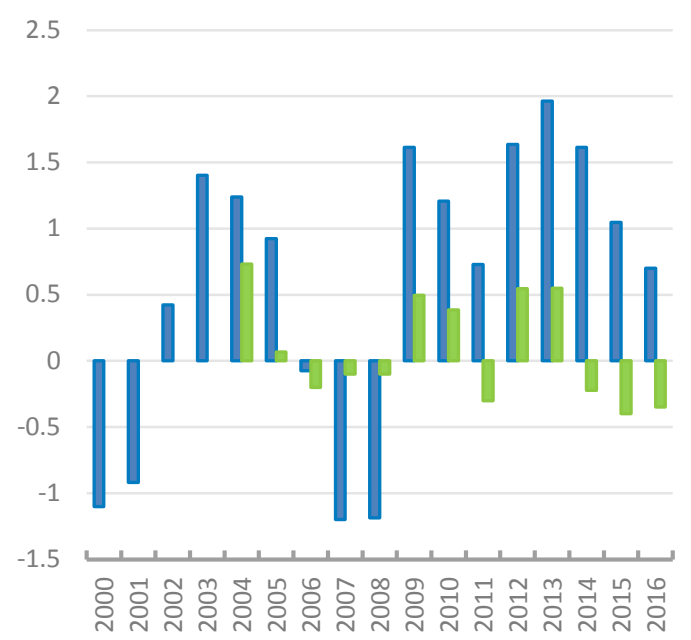

J. Portugal
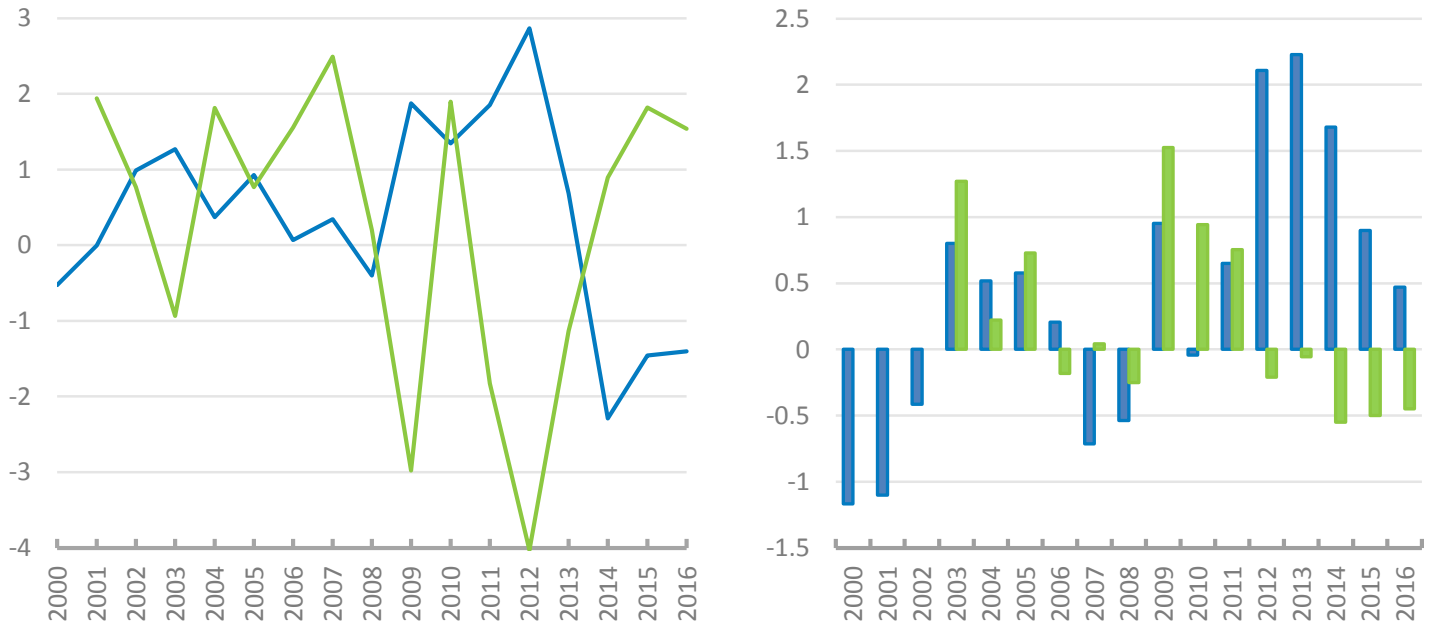

K. Slovak Republic
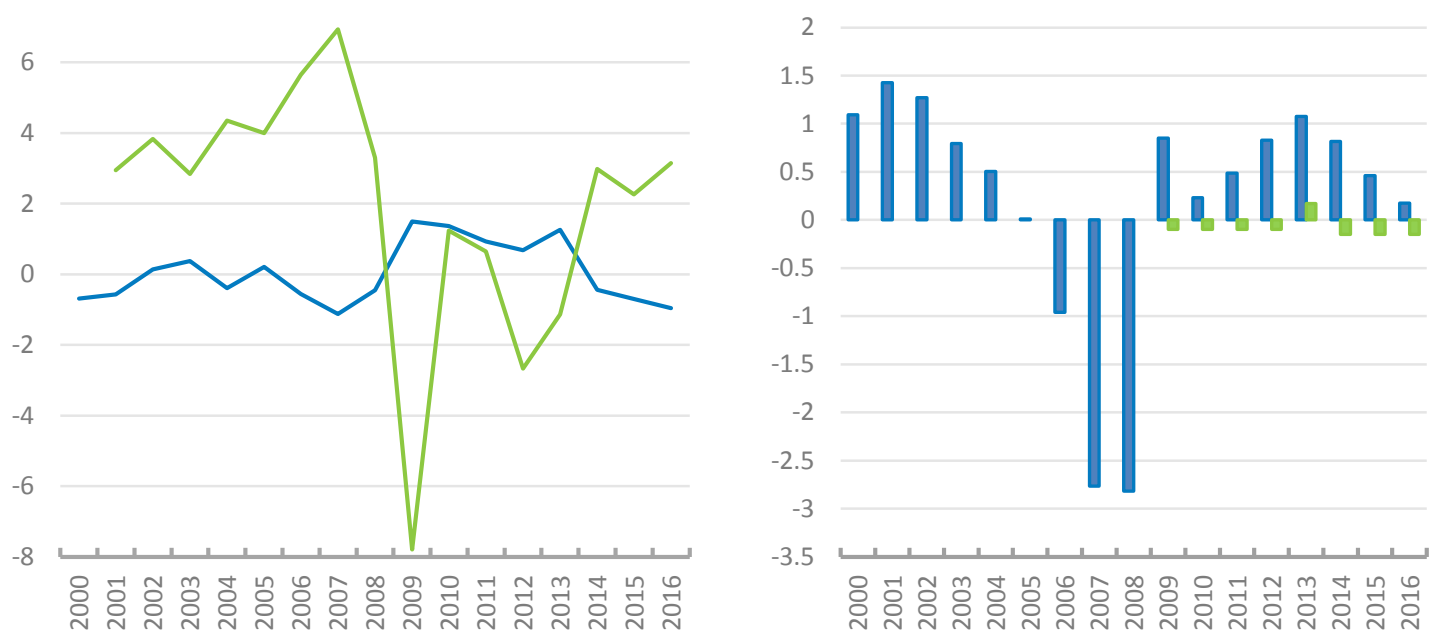
ECO/WKP(2018)45

\section{Slovenia}
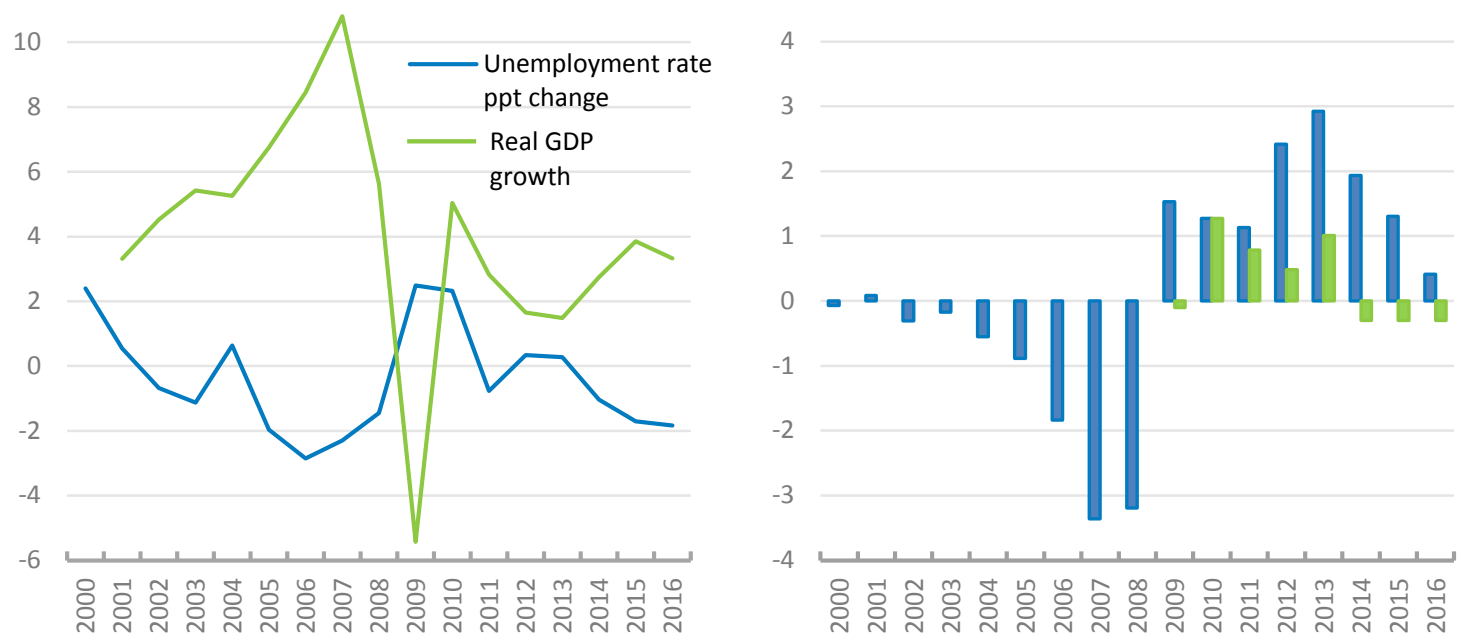

${ }^{1}$ Annual net transfers are expressed as a fraction of GDP and calculated as a difference between the sum of all country pay-outs and contributions. Cyclical deficit in per cent of GDP is obtained from the AMECO database. Change in the unemployment rate is calculated as the year-on-year percentage point deviation. Real GDP growth rate is the year-on-year percent deviation of real GDP compared to previous year. 
Figure A.2. The EURS would improve stabilisation country by country

A. Austria

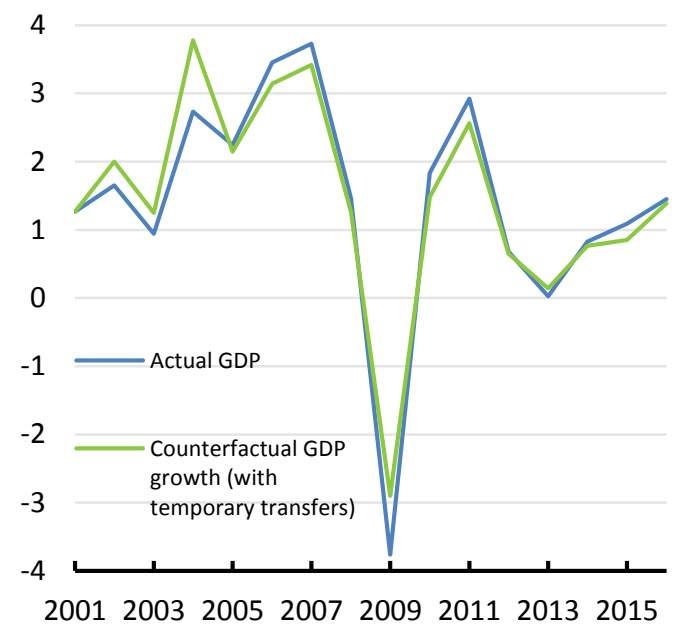

C. Finland

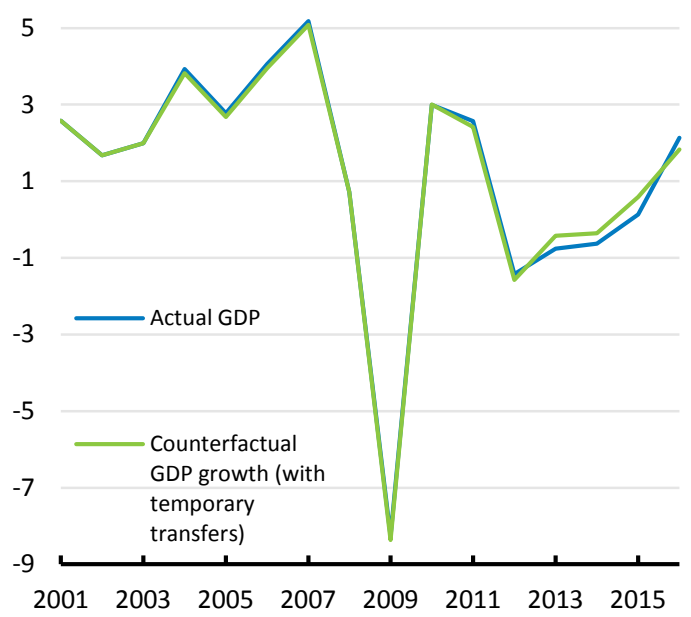

B. Belgium
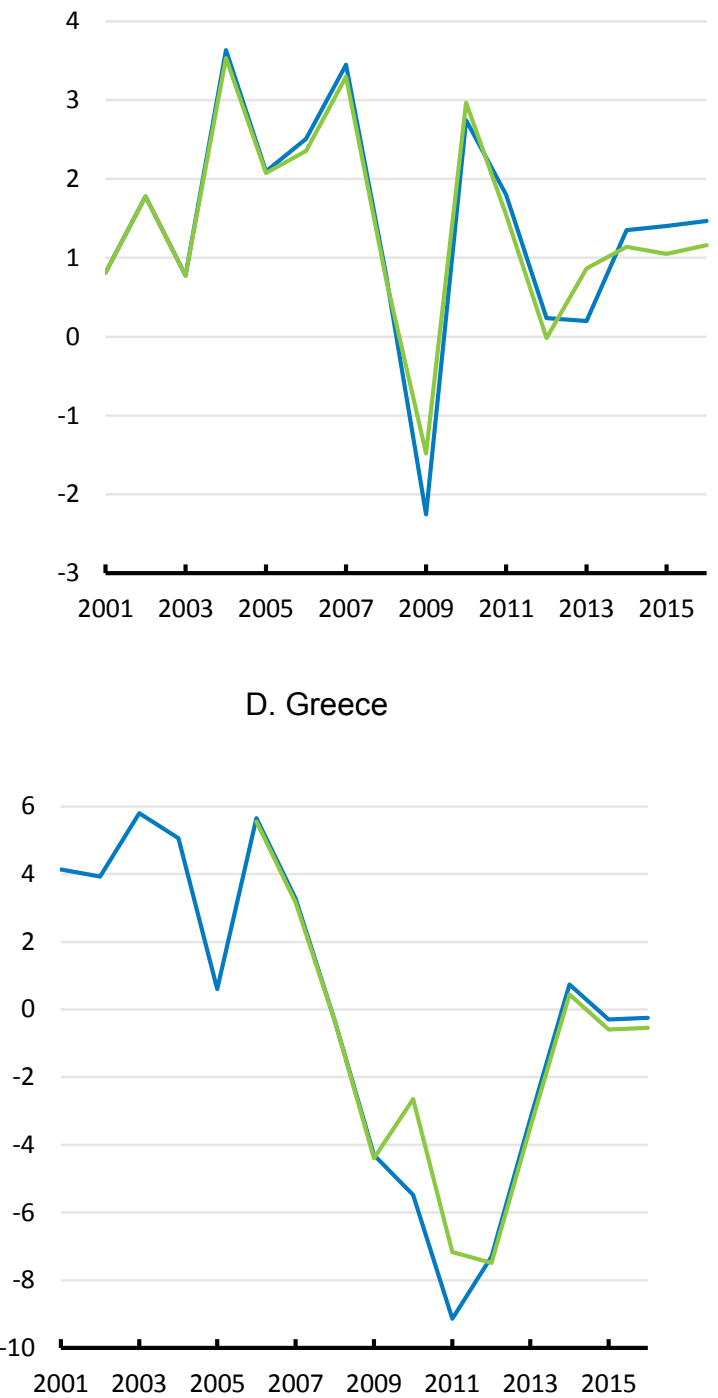
E. Ireland

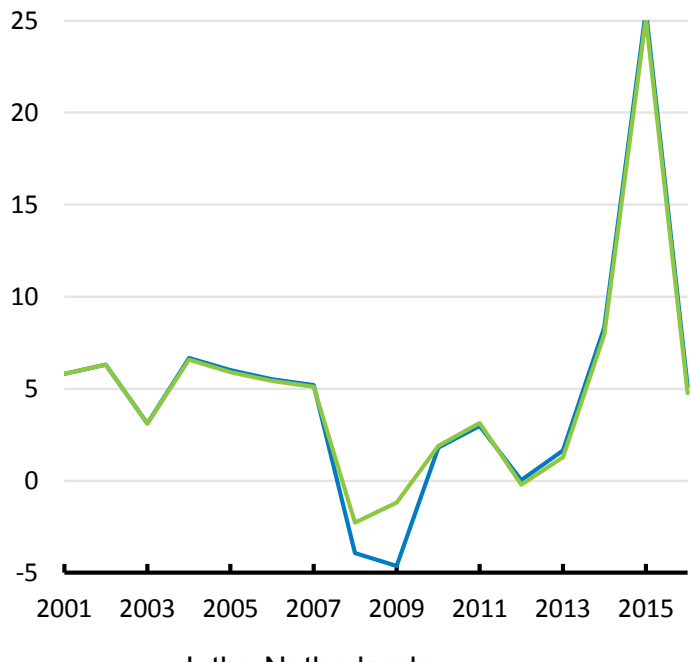

I. the Netherlands

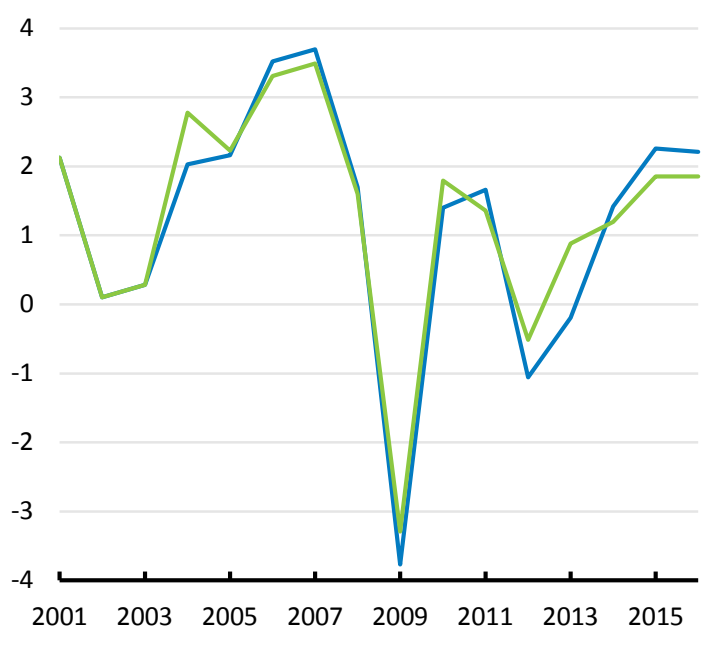

K. Slovak Republic

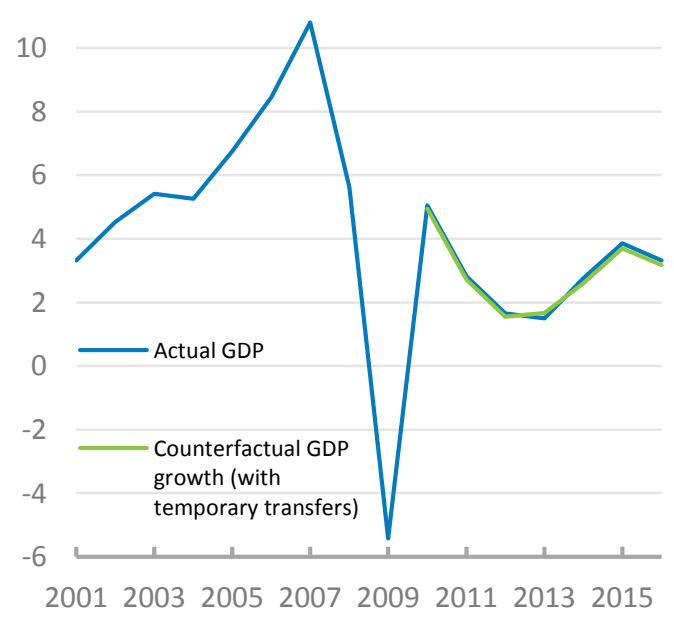

F. Luxembourg



\section{REFERENCES}

Allard, C. et al. (2013), "Toward a fiscal union for the euro area", IMF Staff Discussion Note SDN/13/09, International Monetary Fund, Washington, D.C.

Arnold, N., B. Barkbu, E. Ture, H. Wang and J. Yao (2018), “A central fiscal stabilisation capacity for the euro area", IMF Staff Discussion Note SDN/18/03, International Monetary Fund, Washington, D.C.

Beblavý, M., Gros, D. and I. Maselli (2015), "Reinsurance of national unemployment benefit schemes", CEPS Working document No. 401, Centre for European Policy Studies, Brussels.

Beblavý, M. and K. Lenaerts (2017), "Feasibility and added value of a European Unemployment benefits scheme" (No. 12230). Centre for European Policy Studies, Brussels.

Beblavý, M. and I. Maselli (2014), “An unemployment insurance scheme for the euro area: A simulation exercise of two options", CEPS Special Report No. 98, Centre for European Policy Studies, Brussels.

Carnot, N., Kizior, M. and G. Mourre (2017), "Fiscal stabilisation in the euro area: A simulation exercise", CEB Working Paper No. 17/025, Solvay Brussels School of Economics and Management, Université Libre de Bruxelles.

Claeys, G. (2017), "The missing pieces of the euro architecture”, Policy Contribution Issue no. 28, Bruegel, Brussels.

Claveres, G. and J. Stráský (2018), "Euro area unemployment insurance at the time of zero nominal interest rates", OECD Economics Department Working Paper, Paris.

Dolls, M., Fuest, C., Neumann, D., Peichl, A. and M. Ungerer (2014), "Cost of non-Europe of the absence of an Unemployment Insurance Scheme for the euro area", Report to the European Parliament.

Dullien, S. (2014), A European Unemployment Benefit Scheme: How to provide more stability in the euro zone, Verlag Bertelsmann Stiftung, Gütersloh.

Dullien, S., Fernández, J., López, M., Maas, G., del Prado, D. and J. von Weizsäcker (2018), "Fit for purpose: A German-Spanish proposal for a robust European Unemployment Insurance", Friedrich Ebert Stiftung, Berlin.

Égert, B. and P. Gal (2017), “The quantification of structural reforms in OECD countries: A new framework", OECD Journal: Economic Studies, OECD Publishing, Paris, Vol. 2016/1, http://dx.doi.org/10.1787/eco_studies-2016-5jg1lqspxtvk.

European Commission (2017a), "New budgetary instruments for a stable euro area within the Union framework", Communication COM(2017) 822 final, European Commission, Brussels.

European Commission (2017b), "Reflection paper on the deepening of the Economic and Monetary Union”, COM(2017) 291, European Commission, Brussels.

Feld, L. and S. Osterloh (2013), "Is a fiscal capacity really necessary to complete the EMU?" A paper presented at the workshop "How to build a genuine EMU", Berlin-Genshagen, 30 May. 
ECO/WKP(2018)45

Juncker, J.-C. et al. (2015), “Completing Europe's Economic and Monetary Union”, European Commission, Brussels.

Lellouch, T. and A. Sode (2014), "An unemployment insurance scheme for the euro area", TrésorEconomics No. 132, Ministry of Finance, Paris. 